Amasya Illahiyat Dergisi - Amasya Theology Journal

ISSN 2667-7326 | e-ISSN 2667-6710

Aralık / December 2020, 15: 421-451

\title{
Hanîflerden Zeyd b. Amr b. Nüfeyl'in Hayatı ve Şahsiyeti
}

\author{
Recep ERKOCAASLAN \\ Dr. Öğr. Üyesi, Recep Tayyip Erdoğan Üniversitesi, İlahiyat Fakültesi, \\ İslam Tarihi Anabilim Dalı \\ Assistant Professor, Recep Tayyip Erdogan University, Faculty of Theology, \\ Department of Islamic History \\ Rize, Turkey \\ receperkocaaslan@hotmail.com \\ orcid.org/0000-0001-9811-5524
}

Makale Bilgisi / Article Information

Makale Türü / Article Types: Araştırma Makalesi / Research Article

Geliş Tarihi / Received: 30 Ağustos / August 2020

Kabul Tarihi / Accepted: 10 Ekim / October 2020

Yayın Tarihi / Published: 30 Aralık / December 2020

Yayın Sezonu / Pub. Date Season: Aralık / December

Sayı / Issue: 15 Sayfa / Pages: 421-451

Atıf / Cite as: Erkocaaslan, Recep. "Hanîflerden Zeyd b. Amr b. Nüfeyl'in Hayatı ve Şahsiyeti [Life and Personality of Zayd b. 'Amr b. Nufayl Who was from the Hanīfs]". Amasya ilahiyat Dergisi-Amasya Theology Journal 15 (December 2020): 421-451.

https://doi.org/10.18498/amailad.787937.

İntihal / Plagiarism: Bu makale, en az iki hakem tarafından incelendi ve intihal içermediği teyit edildi. / This article has been reviewed by at least two referees and scanned via a plagiarism software.

Copyright $\odot$ Published by Amasya Üniversitesi, İlahiyat Fakültesi / Amasya University, Faculty of Theology, Amasya, 05100 Turkey. All rights reserved. https://dergipark.org.tr/amailad. 
422 | R. ERKOCAASLAN / Hanîflerden Zeyd b. Amr b. Nüfeyl' in Hayatı ve Şahsiyeti

\section{Life and Personality of Zayd b. 'Amr b. Nufayl Who was from the Hanīfs}

\section{Abstract}

Idolatry was widespread in Mecca and most of Arabia just before the Prophet Muhammad's prophecy. However, there was a small group that was committed to the Prophet Abraham's belief in monotheism. These people, who are called Ḥaniff, tried to stay away from idolatry, Christianity and Judaism and continue the religion of the Prophet Abraham as much as they could reach his knowledge. Even though the intervening years had caused them to forget the sharia of the Prophet Abraham, they were at least trying to stay away from the bad habits of Jāhiliyya, such as drinking and adultery. Also, they did not accept any god other than Allah.

One of the Ḥaniffs was Zayd b. 'Amr who lived and died during the Jāhiliyya. He is a remarkable person because of his characteristics such as criticizing the Meccans for their beliefs, not eating the meat of animals slaughtered on behalf of idols, and saving baby girls who were wanted to be killed by their families. Since there is not any independent study on Zayd b. 'Amr in Turkey, we thought that it would be appropriate to examine this precious person, who was ahead of his contemporaries in terms of both mentality and behavior.

It is not known that when he was born and how old he was when he died. He is a makti person because his mother married her step-son and Zayd b. 'Amr was born by this marriage. Both his explanations and the testimony of other people show that he was the only person who was Haniff in Mecca during his lifetime.

As he pointed out in some of his poems, he had shown respect to idols like his fellow citizens at one time. There is not any information on whether he went through an experience that dissuaded him from this opinion or whether he started believing in the unity of Allāh through his own intellectual deductions. When he realized that it was wrong to worship idols, he visited many towns and sought a right religion. As far as we understand from the narrations, these trips were made more than once to find a right religion. It is understood that he visited many regions such as Yathrib, Khaybar, Fadak, Ayla, Shām, al-Mawșil, al-Jazīra, Balḳā' and Hirā' to find the right religion. Zayd b. 'Amr could not find a religion that made him satisfied during these trips and decided to become committed to the religion of his ancestors, the Prophet Abraham and the Prophet Ismā' $\overline{1}$, as far as he could access the information on it. Because the intervening years had caused this religion to be forgotten, he tried to worship Allah with the very limited knowledge that he had. According to the sources, he made some rituals such as performing prayer and making pilgrimage. In 
addition, like a person who can think clearly, he tried to stay away from bad customs and habits such as drinking, adultery and usury.

After Zayd b. Amr began to criticize his fellow citizens because of wrong practices and beliefs, he was exposed to hostility of Meccans, especially his uncle and his paternal half-sibling called Khatțāb b. Nufayl. Moreover, he had to live in a cave on Hirā' Mountain or to set up in a tent because he was not allowed to enter Mecca.

Zayd b. Amr had one of the most beautiful behaviors that conducted was to save the baby girls who were wanted to be buried by their families and to give these families money to dissuade them from this idea. This behavior is sufficient to show that he was a person to be ahead of his age in terms of mentality and behavior.

After his death, the way of Islam chosen by his wife Fātima bint Ba 'dja, and his children, Sa'īd b. Zayd and 'Ātika bint Zayd shows that he affected his family members positively.

Before the prophecy, Prophet Muhammad met with Zayd b. Amr and helped him to start questioning the customs of Jāhiliyya.

Although there are different narrations on the subject, it is thought that Zayd $b$. Amr probably died in Mecca when the Prophet Muhammad was around thirty five years old and buried at the foot of Hirā Mountain. In many narrations coming from the Prophet Muhammad, it is stated that he will be resurrected as a single ummah. There are also narrations that he deserves heaven.

Keywords: History of Islam, Zayd b. 'Amr b. Nufayl, Prophet Muhammad, Hanīf, Jāhiliyya.

\section{Hanîflerden Zeyd b. Amr b. Nüfeyl'in Hayatı ve Şahsiyeti}

\section{Öz}

Hz. Peygamber'in risâlet ile gönderilmesine yakın zamanlarda Mekke'de ve Arabistan'ın çok büyük bir kısmında putperestlik yaygındı. Ancak hâlâ Hz. İbrâhîm'in tevhit inancına bağlı olan küçük bir zümre bulunuyordu. Hanîf ismi verilen bu kişiler Putperestlik, Hristiyanlık ve Yahudilikten uzak durmaya çalışıyor, güçleri yettiğince ve bilgisine ulaşabildikleri ölçüde Hz. İbrâhîm'in dinini devam ettirmeye çalışıyorlardı. Aradan geçen uzun yıllar Hz. İbrâhîm'in şeriatını büyük ölçüde unutturmuş olsa da onlar en azından Câhiliye'nin içki ve zina gibi kötü alışkanlıklarından uzak durmaya çalışıyorlardı. Allah'tan başka bir tanrıyı da kabul etmiyorlardı. 
424 | R. ERKOCAASLAN / Hanîflerden Zeyd b. Amr b. Nüfeyl' in Hayatı ve Şahsiyeti

Câhiliye döneminde yaşamış ve vefat etmiş olan Hâniflerden biri de Zeyd b. Amr'dı. O, Mekkelileri inançları dolayısıyla eleştirmesi, putlar adına kesilen hayvanların etlerini yememesi ve aileleri tarafından öldürülmek istenen $\mathrm{k} 1 \mathrm{z}$ çocuklarını kurtarması gibi özellikleri sebebiyle oldukça dikkat çeken bir şahsiyettir. Ülkemizde Zeyd b. Amr b. Nüfeyl hakkında müstakil bir çalışma yapılmadığı için hem zihniyet hem de davranış açısından çağdaşlarının bir hayli ilerisinde olan bu kıymetli şahsiyeti özel olarak incelemenin uygun olacağı kanaatine vardık.

Zeyd b. Amr'in ne zaman doğduğu ve kaç yaşında vefat ettiği konusunda bilgimiz bulunmamaktadır. Annesi üvey oğlu ile evlenip bu evlilikten Zeyd b. Amr dünyaya geldiği için kendisi maktî bir kişidir. Hem kendi ağzından hem de başka şahısların şahitliği onun yaşadı̆̆ı dönemde Mekke'de Hanîf olan tek kişi olduğunu göstermektedir.

Bazı şiirlerinde de ifade ettiği üzere kendisi bir dönem diğer hemşerileri gibi putlara tazimde bulunmuştur. Onu bu görüşünden vazgeçiren bir olay yaşanmış mıdır, yoksa kendi aklî çıkarımları sayesinde mi Allah'ın birliğine inanmaya başlamıştır, bu konuda kaynaklarımızda herhangi bir malumat bulunmamaktadır. Zeyd b. Amr putlara ibadet etmenin yanlışlığının farkına varınca pek çok beldeyi ziyaret ederek doğru bir din arayışına girmiştir. Rivayetlerden anladığımız kadarıyla doğru bir din bulabilmek için yapılan bu seyahatler birden fazla kez gerçekleşmiştir. Zeyd b. Amr'ın doğru dini bulabilmek için Yesrib, Hayber, Fedek, Eyle, Şam, Musul, Cezîre, Belkâ ve Hîre gibi pek çok bölgeyi ziyaret ettiği anlaşılmaktadır. Yaptığı bu seyahatler esnasında kalbini mutmain eden bir din bulamayan Zeyd b. Amr bilgisine ulaşabildiği ölçüde ataları Hz. İbrâhîm ve Hz. İsmâîl'in dini üzere kalmaya karar vermiştir. Tabi aradan geçen uzun yıllar bu dinin gerekliliklerini unutturduğu için o, sahip olduğu oldukça sınırlı bilgi üzerinden Allah'a ibadet etmeye çalışmıştır. Kaynaklarımızda onun namaz ve hac ibadeti konusunda yaptığı bazı uygulamalardan bahsedilmektedir. Ayrıca o salim bir aklın da bulabileceği içki, zina ve ribâ gibi kötü adet ve alışkanlıklardan da uzak kalmaya çalışmıştır.

Zeyd b. Amr belli bir noktadan sonra hemşerilerini de yanlış uygulama ve inançları yüzünden eleştirmeye başlayınca Mekkelilerin, özellikle de amcası ve anne bir kardeşi olan Hattâb b. Nüfeyl'in düşmanlığına maruz kalmıştır. Hatta kendisi Mekke'ye sokulmadığı için Hira Dağı'nda bir mağarada veya bu bölgede kurduğu bir çadırda yaşamaya mecbur kalmıştır.

Zeyd b. Amr’ın yaptığı en güzel davranışlardan birisi de aileleri tarafından gömülmek istenen kız çocuklarını kurtarması hatta bu uğurda bazen bu kız 
çocuklarının ailelerine para vermesidir. Bu davranışı da zihniyet ve davranış olarak çağının oldukça ilerisinde bir insan olduğunu göstermesi açısından yeterlidir.

Zeyd b. Amr'ın vefatının ardından eşi Fâtıma bint Ba'ce'nin ve çocukları Saîd b. Zeyd ve Âtike bint Zeyd'in ilk dönemde İslâm'a girmiş olmaları onun aile üyelerini de olumlu yönde etkilediğini göstermektedir.

Zeyd b. Amr nübüvvetten evvel Hz. Peygamber ile görüşerek onun da Câhiliye adetlerini sorgulamaya başlamasına vesile olmuştur.

Yine konu ile ilgili farklı rivayetler bulunmakla birlikte Zeyd b. Amr muhtemelen Hz. Peygamber otuz beş yaş civarındayken Mekke'de vefat etmiş ve Hira Dağı'nın eteğine defnedilmiştir. Hz. Peygamber'den gelen pek çok rivayette onun tek başına bir ümmet olarak haşredileceği ifade edilmektedir. Yine onun Cennetlik olduğuna dair rivayetler de bulunmaktadır.

Anahtar Kelimeler: İslâm Tarihi, Zeyd b. Amr b. Nüfeyl, Hz. Peygamber, Hanîf, Câhiliye.

\section{Giriş}

"Hanîf" kelimesinin kökeni ve manası hakkında ciddi tartışmalar mevcut olmakla birlikte ${ }^{1}$ Müslüman âlimlerin geneli, bu kelimenin meyletmek, yönelmek manalarına gelen "حنف/hanefe" kelimesinden türediğini ifade etmişlerdir. İslâmî kaynaklarda "حنيف/Hanîf” kelimesi "putlara tapmayı reddederek Hz. İbrâhîm'in dinine tabi olan muvahhidler" için kullanılmaktadır. ${ }^{2}$

Kur'ân-1 Kerîm'de "Hanîf" kelimesi tekil olarak on yerde, çoğul şekli olan "hunefâ" ise iki yerde geçmektedir. ${ }^{3}$ Söz konusu âyetlerin birçoğunda "Hanîflik" Hz. İbrâhîm ile irtibatlı olarak ve müşrik olmanın zıttı bir manada kullanılmaktadır. Ayrıca Kur'ân-1 Kerîm'deki:

1 Fr. Buhl, "Hanîf”, Milli Eğitim Bakanlı̆̆̆ İslâm Ansiklopedisi (Eskişehir: MEB Yayınları, 1997), 5/1/215-217; Şaban Kuzgun, "Hanîf", Türkiye Diyanet Vakfı İslâm Ansiklopedisi (İstanbul: TDV Yayınları, 1997), 16/33-35.

2 Ebü'l-Fazl Cemâlüddîn Muhammed b. Mükerrem İbn Manzûr, Lisânü'l-Arab, thk. Abdullah Ali el-Kebîr vd. (Kâhire: Dâru'l-Ma'ârif, ts.), "hanefe", 12/1025-1026; İsmail Cerrahoğlu, "Kur'an-1 Kerim ve Hanîfler", Ankara Üniversitesi İlahiyat Fakültesi Dergisi 11/1 (1963), 81-84.

3 el-Bakara 2/135; Âl-i İmrân 3/67, 95; en-Nisâ 4/125; el-En'âm 6/79, 161; Yûnus 10/105; en-Nahl 16/120, 123; el-Hac 22/31; er-Rûm 30/30; el-Beyyine 98/5. 
426 | R. ERKOCAASLAN / Hanîflerden Zeyd b. Amr b. Nüfeyl' in Hayatı ve Şahsiyeti

"(Raŝ̂lüm!) Sen yüzünü Hanîf olarak dine, Allah insanları hangi fitrat üzere yaratmış ise ona çevir..." 4 âyetinde belirtildiği üzere Hz. Peygamber'e ve ona uyanlara Haniff olmaları emredilmektedir. Bu âyeti: "Allah nezdinde hak din İslâm'dır." 5 âyeti ile birlikte düşünecek olursak "Hanîflik" kavramının İslâm ile aynı olduğu sonucuna varabiliriz. Nitekim bazı hadislerde geçen ifadelerden de Hanîflik ve İslâm'ın aynı manaya geldiği anlaşılmaktadır. ${ }^{6}$

Hanîf ve hunefâ kavramları Câhiliye döneminde bir grup insan için de kullanılmaktaydı. Hz. Peygamber'in risâlet ile gönderilmesine yakın zamanlarda Mekke'de ve Arabistan'ın çok büyük bir kısmında putperestlik yaygındı. Ancak hâlâ Hz. İbrâhîm'in tevhid inancına bağlı olan küçük bir zümre bulunuyordu. Bu kişiler Putperestlik, Hristiyanlık ve Yahudilikten uzak durmaya çalışıyor, güçleri yettiğince ve bilgisine ulaşabildikleri ölçüde $\mathrm{Hz}$. İbrâhîm'in dinini devam ettirmeye çalışıyorlardı. Aradan geçen uzun yıllar Hz. İbrâhîm'in şeriatını büyük ölçüde unutturmuş olsa da onlar en azından Câhiliye'nin içki ve zina gibi kötü alışkanlıklarından uzak durmaya çalışıyorlardı. Allah'tan başka bir tanrıyı da kabul etmiyorlardı. ${ }^{7}$

Hz. Peygamber'e nübüvvet verilmeden önce yaşamış ve vefat etmiş Hanîflerden biri de Zeyd b. Amr'dı. O, Mekkelileri inançları dolayısıyla eleştirmesi, putlar adına kesilen hayvanların etlerini yememesi ve aileleri tarafından öldürülmek istenen kız çocuklarını kurtarması gibi özellikleri sebebiyle oldukça dikkat çeken bir şahsiyettir. Ülkemizde Zeyd b. Amr b. Nüfeyl hakkında müstakil bir çalışma yapılmadığı için hem zihniyet hem de davranış açısından çağdaşlarının bir hayli ilerisinde olan bu kıymetli şahsiyeti özel olarak incelemenin uygun olacağ 1 kanaatine varıldı.

4 Hayrettin Karaman vd., Kur'ân-ı Kerîm ve Açılamalı Meâli (Ankara: TDV Yayınları, 2005), er-Rûm 30/30; Yûnus 10/105.

5 Âl-i İmrân 3/19.

6 Ebû Abdillâh Muhammed İbn Sa'd, et-Tabakâtü'l-kübrâ, thk. Muhammed Abdülkâdir Atâ (Beyrût: Dâru'l-Kütübi'l-İlmiyye, 2012), 1/151; Ebû Abdillâh Ahmed b. Hanbel, el-Müsned (İstanbul: Çağrı Yayınları, 1992), 1/236; Ebû Abdillâh Muhammed elBuhârî, el-Câmi'u's-sahîh (İstanbul: Çağrı Yayınları, 1992), "Îmân", 29; Ebü'l-Hüseyin Müslim b. el-Haccâc Müslim, el-Câmi'u's-sahîh (İstanbul: Çağrı Yayınları, 1992), "Cennet", 63.

7 Cerrahoğlu, "Kur'an-1 Kerim ve Hanîfler", 81-92; Cevâd Ali, el-Mufassal fî târîhi'l'Arab kable'l-ìslâm (Bağdâd: Câmiatü Bağdâd, 1993), 6/449-511; Kuzgun, "Hanîf", 16/33-39. 
Çalışma açısından en önemli konulardan birisi de Zeyd b. Amr'ın nübüvvetten önce Hz. Peygamber ile karşılaşması olayıydı. Ancak bu rivayet hakkında sened ve metin üzerinden ayrıntılı bir değerlendirme yapmaya çalışmak, maalesef çalışmanın bir makale boyutunun üzerine çıkmasına sebep oldu. Bu nedenle bu rivayeti Hz. Peygamber'in nübüvvetten önceki dinî durumu hakkındaki diğer rivayetlerle birlikte, müstakil bir çalışma olarak ele almanın daha uygun olacağı kanaatine varıldı. Üstelik bu şekilde çalışmanın ana hedefi olan Zeyd b. Amr da ikinci plana düşmemiş oldu. Dolayısıyla çalışmada Hz. Peygamber'in Zeyd b. Amr ile karşılaşması olayı ayrıntılara girilmeden özet bir şekilde aktarılacaktır.

Kaynaklarımızda Zeyd b. Amr hakkındaki malumatın oldukça az olması ve zaten az olan bu bilgilerin pek çok farklı rivayet oluşturacak şekilde birbiri içerisine geçmiş olması başlıca dezavantajlar olarak zikredilebilir.

\section{Zeyd b. Amr Hakkında Genel Bilgiler}

Nesebi, Zeyd b. Amr b. Nüfeyl b. Abdüluzzâ b. Riyâh b. Abdullah b. Kurt b. Rezâh (Rizâh) b. Adî b. Ka'b b. Lüey el-Kuraşî el-Adevî şeklindedir. ${ }^{8}$ Onun soyu Ka'b b. Lüey'de Hz. Peygamber'in soyu ile birleşir.

Zeyd'in babası Amr, babası Nüfeyl'in vefatından sonra üvey annesi olan Hanne/Hayye bint Câbir ${ }^{9}$ ile evlenmişti. ${ }^{10}$ Câhiliye

8 İbn Sa'd, et-Tabakât, 3/289-290; Ebû Muhammed Alî b. Ahmed b. Saîd İbn Hazm, Cemheretü ensâbi'l-Arab, thk. Abdüsselâm Muhammed Hârûn (Kâhire: Dâru'l-Ma'ârif, 1982), 150-151; Ebû Ömer Cemâleddîn Yûsuf İbn Abdilber, el-İstî́âb fî ma'rifeti'l-ashâb, thk. Ali Muhammed el-Becâvî (Beyrût: Dâru'1-Cîl, 1992), 2/614; Ebü'1-Kâsım Ali b. elHasen İbn Asâkir, Târîhu medîneti Dımaşk, thk. Muhibbüddîn Ebî Sa‘îd Ömer b. Garâme el-Amravî (Beyrût: Dâru'l-Fikr, 1995), 19/493; Ebü'l-Hasen İzzeddîn Ali İbnü'l-Esîr, Üsdü'l-gâbe fî ma 'rifeti's-sahâbe, thk. Halîl Me'mûn Şeyhâ (Beyrût: Dâru'lMa'rife, 2009), 2/251; Ebü'l-Fidâ İmâdüddîn İsmâîl b. Şihâbiddîn Ömer İbn Kesîr, elBidâye ve'n-nihâye, thk. Abdullah b. Abdilmuhsin et-Türkî (Cîze: Hicr, 1997), 3/316; Cevâd Ali, el-Mufassal, 6/469.

9 Ebû Abdillâh Mus'ab b. Abdillâh b. Mus'ab ez-Zübeyrî, Kitâbü Nesebi Kureyş, thk. E. Lévi-Provençal (Kâhire: Dâru'l-Ma'ârif, 1951), 364; İbn Asâkir, Târîh, 19/494; Hâmid Hamîd Atıyye, "Zeyd b. Amr b. Nüfeyl el-Adevî", Mecelletü Diyâlâ 44 (2010), 597; Halit Özkan, "Zeyd b. Amr", Türkiye Diyanet Vakfı İslâm Ansiklopedisi (İstanbul: TDV Yayınları, 2013), 44/316; Zeyd b. Amr'ın annesinin ismi bazı çalışmalarda Haydâ' bint Hâlid olarak da geçmektedir. Özkan, "Zeyd b. Amr”, 44/316. 
428 | R. ERKOCAASLAN / Hanîflerden Zeyd b. Amr b. Nüfeyl' in Hayatı ve Şahsiyeti

döneminde babaları öldügü zaman oğulları, öz olmayan anneleri ile evlenebilirlerdi. Bu nikâh çeşidine de "Nikâh-1 makt" denilirdi. Bu nikâh çeşidi: "Geçmişte olanlar bir yana, babalarınızın evlendiği kadınlarla evlenmeyin; çünkü bu bir hayâsızlıktır, iğrenç bir şeydir ve kötü bir yoldur."11 âyeti ile kaldırıldı. ${ }^{12} \mathrm{Bu}$ evliliklerden dünyaya gelen çocuklara da "maktî" denilirdi. ${ }^{13}$ Dolayısıyla Zeyd b. Amr böyle bir evlilik sonucu dünyaya gelmiş, maktî biriydi.

Hz. Ömer'in babası Hattâb, Zeyd b. Amr'ın hem amcası hem de anne bir erkek kardeşiydi. ${ }^{14}$ Hanne bint Câbir, Nüfeyl'den Hattâb'1 dünyaya getirdikten sonra Amr ile evlenmiş ve bu evlilikten de Zeyd dünyaya gelmişti. Böylelikle Zeyd'in amcası olan Hattâb, onunla aynı zamanda anne bir kardeş olmuştu. ${ }^{15}$

Zeyd b. Amr'ın tespit edebildiğimiz kadarıyla iki eşi vardı. Bunlardan biri Huzâa kabilesinden Fâtıma bint Ba'ce olup o, ilk Müslüman olan kadınlardan biriydi. ${ }^{16}$

Zeyd b. Amr'ın diğer eşi Safiyye bint Hadramî'ydi. Rivayetlerden anlaşıldığı kadarıyla Safiyye, Hanîf olan kocası ile anlaşamıyordu. ${ }^{17}$

10 Ebû Abdullah Muhammed İbn İshâk, Sîretü İbn İshâk, thk. Muhammed Hamîdullah (Fas: y.y., 1976), 97; Ebû Muhammed Cemâleddîn Abdülmelik İbn Hişâm, es-Sîretü'nnebeviyye, thk. Mustafa es-Sakâ vd. (Beyrût: Dâru'l-İhyâi't-Türâsi'l-Arabî, 1994), 1/268; İbn Kesîr, el-Bidâye, 3/316.

11 en-Nisâ $4 / 22$.

12 Ebû Mansûr Muhammed b. Muhammed b. Mahmûd el-Mâtürîdî, Te'vîlâtü'l-Kur'ân, thk. Bekir Topaloğlu vd. (İstanbul: Mizan Yayınevi, 2006), 3/106-107; İbn Manzûr, "makt", 47/4242; Mustafa Öztürk, Cahiliyeden İslamiyet'e Kadın (Ankara: Ankara Okulu Yayınları, 2013), 37-38.

13 Ebü'l-Kâsım Mahmûd b. Ömer b. Muhammed el-Hârizmî ez-Zemahşerî, el-Keşşâf an hakâ'ikı gavâmizi't-tenzîl ve uyûni'l-ekâvîl fî̀ vücûhi't-te'vîl, thk. Âdil Ahmed Abdülmevcûd - Ali Muhammed Mu'avviz (Riyâd: Mektebetü'l-Ubeykân, 1998), 2/48; Öztürk, Cahiliyeden İslamiyet'e Kadın, 38.

14 Bazı kaynaklarda Hattâb'ın yanı sıra Abdünühm'ün de ismi geçmektedir. Zübeyrî, Kitâbü Nesebi Kureyş, 364; İbn Asâkir, Târîh, 19/494.

15 İbn İshâk, es-Sîre, 97; İ̉n Hişâm, es-Sîre, 1/268; İbn Asâkir, Târîh, 19/495; İbnü'l-Esîr, Üsdü'l-gâbe, 2/252; İbn Kesîr, el-Bidâye, 3/316; Özkan, "Zeyd b. Amr”, 44/316.

16 İbn Sa'd, et-Tabakât, 3/290; İbn Abdilber, el-İstî́âb, 2/614; Ebü'l-Fazl Şihâbeddîn Ahmed b. Ali İbn Hacer el-Askalânî, el-İsâbe fî temyîzi's-sahâbe (Beyrût: Dâru'l-Fikr, 2001), 2/344.

17 İbn İshâk, es-Sîre, 98; İbn Hişâm, es-Sîre, 1/265-266; İbn Kesîr, el-Bidâye, 3/318. 
Hatta Zeyd b. Amr karısını, kendisini müşrik olan amcası Hattâb’a şikâyet ettiği için bir şiirinde eleştirmişti. ${ }^{18}$

Zeyd b. Amr'ın tespit edebildiğimiz kadarıyla bir oğlu ve bir kızı bulunmaktaydı. Oğlu, ilk Müslümanlardan ve Aşere-i mübeşşere'den olan Saîd b. Zeyd'di. ${ }^{19}$ Saîd b. Zeyd ve karısı Fâtıma bint Hattâb Hz. Peygamber henüz Dârülerkam'da davete başlamadan önce Müslüman olmuşlardı. ${ }^{20}$ Saîd b. Zeyd'in Hz. Peygamber'e nübüvvetin verildiği ilk günlerde Müslüman olmasında babası Zeyd b. Amr'ın örnek yaşantısının büyük bir etkisi olmuş olmalıdır. ${ }^{21}$

Zeyd b. Amr'ın tek kızı ise Âtike bint Zeyd olup annesi Ümmü Kürz bint Hadramî olarak zikredilmektedir. ${ }^{22}$ Muhtemelen Ümmü Kürz ismi, Zeyd b. Amr'ın yukarıda eşi olarak zikrettiğimiz Safiyye bint Hadramî'nin künyesi olmalıdır. Âtike, erkek kardeşi Saîd b. Zeyd gibi Müslüman olmuş ve Medine' ye hicret etmişti. ${ }^{23}$

\section{Zeyd b. Amr'ın IV. Ficâr Savaşı'na Katılması}

Zeyd b. Amr hakkındaki en eski bilgilerimizden biri Kureyş'in de dâhil olduğu Ficâr Savaşı hakkındadır. IV. Ficâr Savaşı müttefik KureyşKinâne ile Kays Aylân kabileleri arasında meydana gelmişti. Benî Kinâne kabilesinden Berrâd b. Kays'ın Hevâzin kabilesinden Urve b. Utbe'yi haksız bir şekilde öldürmesi bu savaşa sebebiyet vermiştir. ${ }^{24}$

18 İbn Hişâm, es-Sîre, 1/266; Cevâd Ali, el-Mufassal, 6/475; Atıyye, "Zeyd b. Amr”, 601.

19 Ahmed b. Hanbel, el-Müsned, 1/187, 193; Ebû Abdillâh Muhammed b. Yezîd İbn Mâce, es-Sünen (İstanbul: Çağrı Yayınları, 1992), "Mukaddime”, 11; Süleymân b. elEş'as b. İshâk es-Sicistânî Ebû Dâvûd, es-Sünen (İstanbul: Çağrı Yayınları, 1992), "Sünne", 9; Ebû Îsâ Muhammed b. Îsâ b. Sevre et-Tirmizî, es-Sünen (İstanbul: Çağrı Yayınları, 1992), "Menâkıb", 25, 27; Ebû Abdillâh Muhammed el-Hâkim en-Nîsâbûrî, Müstedrek ale's-Sahîhayn, thk. Mustafa Abdülkâdir Atâ' (Beyrût: Dâru'l-Kütübi'lİlmiyye, 2002), 3/498. Saîd b. Zeyd hakkında ayrıntılı bilgi için bk. İsmail Pırlanta, Hz. Said bin Zeyd (İstanbul: Beyan Yayınları, 2020), 1-96.

20 İbn Sa'd, et-Tabakât, 3/292, 8/209; Ebü'l-Hasen Ahmed b. Yahyâ el-Belâzürî, Ensâbü'leşrâf, thk. Muhammed Hamîdullah vd. (Beyrût: Dâru'l-Fikr, 1417), 10/470; el-Hâkim en-Nîsâbûrî, Müstedrek, 3/496.

21 krş. Cevâd Ali, el-Mufassal, 6/476.

22 İbn Sa'd, et-Tabakât, 8/208; Atıyye, "Zeyd b. Amr", 597.

23 İbn Sa'd, et-Tabakât, 8/208; İbn Hacer el-Askalânî, el-İsâbe, 7/184.

24 Belâzürî, Ensâb, 1/100-101; Hüseyin Algül, "Ficâr", Türkiye Diyanet Vakfi İslâm Ansiklopedisi (İstanbul: TDV Yayınları, 1996), 13/52. 
430 | R. ERKOCAASLAN / Hanîflerden Zeyd b. Amr b. Nüfeyl' in Hayatı ve Şahsiyeti

$\mathrm{Bu}$ savaşta Kureyş kabilesinden her ailenin başında ayrı bir komutan bulunuyordu. Benî Adî kabilesine de Zeyd b. Amr b. Nüfeyl komuta etmişti. ${ }^{25}$

\section{Zeyd b. Amr'ın Hak Dini Arayışı}

Kureyşlilerin putlar için kurban kestikleri bir bayram gününde Zeyd b. Amr, Varaka b. Nevfel, Osman b. Huveyris ve Ubeydullah b. Cahş birbirlerine: "Vallahi! Kavmimiz kesinlikle doğru bir yolda değildir. İbrâhîm'in dininden ayrılarak ona muhalefet ediyorlar. $\mathrm{Ne}$ zarar ne de fayda vermeye gücü yetmeyen putlara tapılmaz. Kendimize yeni bir din arayalım." dediler. Bu konuşmalardan sonra ismi zikredilen kişiler hak dini bulabilmek için seyahatlere çıktılar. Bu yolculuklar neticesinde Varaka b. Nevfel, Ubeydullah b. Cahş ve Osman b. Huveyris Hristiyanlık dinine girdiler. Bu grubun içerisinde işi ve davranışları en düzgün olan kişi Zeyd b. Amr'dı. Zeyd putlara tapmadığı gibi Hristiyanlık ve Yahudilik gibi başka bir dini de benimseyemedi. O, İbrâhîm'in dini üzere kalarak Allah'1 birliyor, O'ndan başkalarından uzak duruyordu. Kavminin putlar için kestiği kurbanların etlerinden yemiyordu. Onlara muhalefet ederek de bu tavrını açıkça ortaya koyuyordu. 26

Bazı rivayetlerde Zeyd b. Amr'ın doğru dini bulabilmek amacıyla yaptığı bu yolculuk hakkında biraz daha fazla ayrıntı bulunmaktadır. Zeyd b. Amr doğru dini bulabilmek için Şam bölgesine gittiğinde ilk olarak bir Yahudi âlimle görüştü. $O$, Yahudi âlime hak dini aradığını ve beğendiği takdirde o dine girmek istediğini söyledi. Bunun üzerine Yahudi âlim: "Allah'ın gazabından nasibine düşeni almadığın müddetçe bizim dinimize giremezsin." dedi. Bunun üzerine Zeyd: "Ben zaten Allah'ın gazabından kaçıyorum. Asla Allah'ın gazabından bir şey yüklenmek de istemiyorum. Bana bundan başka bir yol gösterebilir misin?" dedi. Yahudi: "Bu Ancak Hanîf dini olabilir. Bu İbrâhîm'in dinidir. O ne Yahudi ne de Hristiyan'dı. Allah'tan başkasına da kulluk etmezdi." dedi. Zeyd b. Amr, Yahudi ile görüştükten sonra Hristiyan bir

25 Ebû Ca'fer Muhammed İbn Habîb, el-Muhabber, thk. İlse Lichtenstadter (Beyrût: Dârü'l-Âfâki'l-Cedîde, ts.), 170; Belâzürî, Ensâb, 1/102; Michael Lecker, “Zayd b. 'Amr", The Encyclopaedia of Islam, New Edition, ed. C. E. Bosworth vd. (Leiden: Brill, 2002), 11/474.

26 İbn İshâk, es-Sîre, 95-96; İ̉n Hişâm, es-Sîre, 1/259-261; İbn Asâkir, Târîh, 19/494-495; Ebû Abdillâh Şemsüddîn Muhammed b. Ahmed b. Osmân ez-Zehebî, Târîhu'l-İslâm ve vefeyâtü'l-meşâhîr ve'l-a lâm (Beyrût: Dâru'l-Kitâbi'l-Arabî, 1990), 2/90-91. 
âlimin yanına giderek hak dini aradığını ve bulduğu takdirde o dine girmek istediğini söyledi. Hristiyan âlim: "Allah'ın lanetinden payına düşeni almadığın sürece bizim dinimize giremezsin." dedi. Zeyd b. Amr da: "Ben zaten Allah'ın lanetinden kaçıyorum. Asla Allah'ın lanetinden bir şey yüklenmek de istemiyorum. Bana bundan başka bir yol gösterebilir misin?" dedi. Hristiyan âlim de: "Bu ancak Hanîf dini olabilir. Bu İbrâhîm'in dinidir. O ne Yahudi ne de Hristiyan'd1. Allah'tan başkasına da kulluk etmezdi." dedi. Zeyd b. Amr, Yahudi ve Hristiyan âlimlerin Hz. İbrâhîm hakkında söylediklerini işitince onların yanlarından ayrıldıktan sonra ellerini kaldırarak: "Allah'ım İbrâhîm'in dini üzere olduğuma seni şahit tutuyorum." dedi. ${ }^{27}$

Maalesef Zeyd b. Amr hakkındaki zaten az olan bilgiler pek çok farklı rivayet oluşturacak şekilde birbiri içerisine geçmiştir. Bu rivayetlerin bazıları Zeyd b. Amr'ın doğru dini bulabilmek için yaptığı seyahatlerin birden fazla kez gerçekleştiği izlenimini uyandırmaktadır. Bir rivayete göre Zeyd b. Amr, Mekke'den ayrılarak Hanîflik hakkında bilgi bulabilmek için seyahat etmek niyetindeydi. Ancak Zeyd ne zaman buna niyetlense hanımı Safiyye bint Hadramî bu durumu Hattâb b. Nüfeyl'e haber veriyordu. Sonunda Zeyd b. Amr, Hz. İbrâhîm'in dini hakkında bilgi alabileceği yetkin bir kişi bulabilmek maksadıyla yola çıktı. Sırasıyla Şam, Musul ve Cezîre bölgelerine seyahat etti. Nihayet Zeyd, Belkâ bölgesinde bulunan ve Hristiyanlık konusunda çok bilgili olan bir rahibin yanına geldi. Zeyd, bu rahipten Hz. İbrâhîm'in dini olan Hanîflik hakkında kendisine bilgi vermesini istedi ancak rahip: "Hakkında bilgi sahibi olmak istediğin din hakkında bugün, sana bilgi verebilecek herhangi bir kimse bulunmuyor. $\mathrm{O}$ dinle ilgili herhangi bir malumatı olanlar ölüp gittiler. Ancak senin geldiğin topraklardan İbrâhîm'in dini olan Hanîflik üzere gönderilecek peygamberin çıkışı yakındır. Memleketine geri dön. Onun zamanı geldi yakında o peygamber gönderilecektir." dedi. Bu bölgede kaldığı süre içerisinde

27 Buhârî, "Menâkıbü'l-Ensâr", 24; Ebû Bekr Ahmed b. el-Hüseyn b. Alî el-Beyhakî, Delâilü'n-nübüvve ve ma'rifetü ahvâli sâhibi'ş-şerî'a, thk. Abdülmu'tî Kal'acî (Beyrût: Dâru'l-Kütübi'l-İlmiyye, 1988), 2/123; İbn Asâkir, Târîh, 19/498-499, 503; Zehebî, Târîhu'l-İslâm, 2/86-87. 
432 | R. ERKOCAASLAN / Hanîflerden Zeyd b. Amr b. Nüfeyl' in Hayatı ve Şahsiyeti

Yahudilik ve Hristiyanlık hakkında da bilgi sahibi olan Zeyd b. Amr bu iki dini de beğenmemişti...28

\section{Vermesi}

\section{Zeyd b. Amr'ın Bir Peygamber Geleceğine Dair Bazı Bilgiler}

Bazı rivayetlerde Zeyd b. Amr'ın yaptığı yolculuk veya yolculuklar esnasında bazı din adamlarından yakın zamanda bir peygamberin çıkacağını öğrendiği kaydedilmektedir. Bu rivayetlerde Belkâ $^{29}$ veya Musul ${ }^{30}$ bölgesinde yaşayan bir rahibin Zeyd b. Amr'a aradığı dinin yakında Mekke'de ortaya çıkacağını haber verdiği kaydedilir.

İlk Müslümanlardan Âmir b. Rebîa da bu konuyla ilgili olarak Zeyd b. Amr ile aralarında geçen bir diyaloğu şöyle aktarmıştır: "Zeyd b. Amr dinî arayış içerisinde bir insan olup Yahudilik, Hristiyanlık ve Putperestlikten nefret ederdi... Bir gün bana: 'Ey Âmir! Ben kavmime muhalefet ederek İbrâhîm'in dinine tabi oldum. İbrâhîm'in, İsmâîl'in ve onun soyundan gelenlerin kulluk ettiği Allah'a kulluk ediyorum. Onlar namazlarını bu kıbleye doğru kılarlardı. Ben İsmâ̂l' in soyundan bir kişinin peygamber olarak gönderileceğini, ancak ömrümün buna yetmeyeceğini düşünüyorum. Ben onun peygamberliğine şehadet ediyor ve onun getirdiklerini tasdik ediyorum. Eğer ona yetişirsen kendisine benim de selamımı ilet.' dedi. Rasûlullah peygamberliğini ilan ettiği zaman yanına giderek Müslüman oldum. Zeyd b. Amr'ın bana söylediklerini kendisine ilettim. Rasûlullah da Zeyd'in selamını alıp kendisine rahmet diledikten sonra: "Ben onu Cennet'te elbiselerini sürüklerken gördüm." buyurmuştur. ${ }^{31}$

Yine bu rivayetle bağlantılı olan bazı rivayetlerde Zeyd b. Amr'ın gelecek olan peygamberi tarif ederken şu sözleri söylediği

28 İbn İshâk, es-Sîre, 98-99; İ̉n Hişâm, es-Sîre, 1/265-268; İbn Asâkir, Târîh, 19/497-498; İbn Kesîr, el-Bidâye, 3/318-319; krş. İbn Habîb, el-Muhabber, 172; Belâzürî, Ensâb, $10 / 468$.

29 İbn İshâk, es-Sîre, 98-99; İ̉n Hişâm, es-Sîre, 1/265-268; İbn Asâkir, Târîh, 19/497-498; İbn Kesîr, el-Bidâye, 3/318-319.

30 Ebû Dâvûd Süleymân b. Dâvûd b. el-Cârûd et-Tayâlisî, el-Müsned, thk. Muhammed b. Abdülmuhsin et-Türkî (Cîze: Hicr, 1999), 1/189-190; Beyhakî, Delâilü'n-nübüvve, 2/123-124; İbn Abdilber, el-İstî́âb, 2/616-617; İbn Asâkir, Târîh, 19/500.

31 İbn Sa'd, et-Tabakât, 3/290; İbn Kesîr, el-Bidâye, 3/322-323; İbn Hacer el-Askalânî, elİsâbe, 2/251-252; krş. Belâzürî, Ensâb, 10/467; Ebû Ca'fer Muhammed b. Cerîr b. Yezîd el-Âmülî et-Taberî, Târîhu'l-ümem ve'l-mülûk (Beyrût: Dâru'l-Kütübi'l-İlmiyye, 2012), $1 / 529$. 
aktarılmaktadır: "Ne uzun ne de kısa boyludur. Saçı ne az ne de çoktur. Gözünde sürekli kırmızılık vardır. İki omuzu arasında peygamberlik mührü bulunur. İsmi Ahmed'dir. Bu beldede doğacak ve yine bu beldede peygamber olacaktır. Sonra kavmi getirdiği şeyi kötü görerek onu buradan çıaracaktır. Bu sebeple Yesrib'e hicret edecek ve dini orada yayılacaktır. Sakın onun dininden gafil olma! Çünkü ben İbrâhîm'in dinini aramak için pek çok beldeyi dolaştım. Bu beldelerde kendisi ile konuştuğum Yahudi, Hristiyan ve Mecusiler: 'Aradığın din yakında gelecektir. $O$ peygamberden sonra başka bir peygamber de gelmeyecektir.' dediler. Ayrıca bu peygamberin sana anlattığım özelliklerini bana aynıla anlattılar." 32

Zeyd b. Amr'ın yakında bir peygamber geleceğini haber verdiğini aktaran bir rivayet de oğlu Saîd b. Zeyd tarafından aktarılmıştır. Zeyd b. Amr oğlu Saîd'e: “Ey oğulcuğum! Kuşkusuz ben Ehl-i kitâb'dan beldemizde bir peygamberin ortaya çıkacağını haber verdiklerini işittim. Şayet onun geldiği zamana ulaşırsan, ona tabi ol. Onunla birlikte savaş. Ĕger o peygamber olarak gönderilmeden önce ben ölürsem, ona tabi olmaktan ve ona yardım etmekten vazgeçme. İnsanlardan ona ilk iman eden sen ol. Kuşkusuz kavmin dalalet üzerinedir." dedi. Hz. Peygamber'e nübüvvet verilip insanları ortağ inanmaya davet etmeye başladığ 1 zaman Saîd kavminden gizli bir şekilde gelerek Müslüman oldu. Saîd b. Zeyd: "İslâm'a girdiğimi oldukça uzun bir süre gizledim." demiştir. ${ }^{33}$

Ayrıca bir rivayette Zeyd b. Amr ve Varaka b. Nevfel'in Fil Olayı'ndan sonra Necâş̂̀'nin yanına giderek kendisiyle konuştukları aktarılmaktadır. Bu üç kişinin kendi aralarında yaptıkları konuşmalarda yakın bir zamanda bir peygamberin Mekke'de ortaya çıkacağı ifade edilmektedir. Ancak rivayet tamamen putların konuşması, gökten inen yeşil kanatlı adamın serdiği yaygının yeryüzünü kaplaması ve rüyada yerden çıkan başın konuşması gibi olağanüstü anlatımlardan oluşmaktadır, üstelik tespit edebildiğimiz kadarıyla tek bir kaynak tarafından aktarılmıştır. ${ }^{34}$ Dolayısıyla oldukça uzun olan bu rivayetin itimat edilebilecek bir yanı olduğunu düşünmediğimiz için buraya almayı uygun görmedik. Ancak rivayetin bizi götürdüğü bir sonuç

32 Taberî, Târîh, 1/529; İbn Asâkir, Târîh, 19/504; İbn Kesîr, el-Bidâye, 3/323.

33 Belâzürî, Ensâb, 10/469-470; krş. Belâzürî, Ensâb, 10/470.

34 İbn Kesîr, el-Bidâye, 3/592-594. 
434 | R. ERKOCAASLAN / Hanîflerden Zeyd b. Amr b. Nüfeyl' in Hayatı ve Şahsiyeti

olarak şunu ifade edebiliriz: Hz. Peygamber'in nübüvvetinden önce meydana gelen olağanüstü haller üzerine kurgulanan rivayetlerde Zeyd b. Amr ve Varaka b. Nevfel'in isimleri de kullanılmıştır.

Doğrulukları şüpheli olmakla birlikte, siyer kaynaklarımızdaki pek çok rivayette insanların o dönemde bir peygamber beklentisi içerisinde bulundukları aktarılmaktadır. ${ }^{35}$ Üstelik Kur'ân-1 Kerîm'de de bildirildiği üzere Ehl-i kitâb’ın bir kısmı ellerindeki kutsal kitaplar vesilesiyle $\mathrm{Hz}$. Îsâ'dan sonra bir peygamber geleceğini biliyorlardı. ${ }^{36}$ Dolayısıyla pek çok din adamı ile görüşen Zeyd b. Amr'ın bu konuda bazı şeyler öğrenmesi ihtimal dâhilindedir. Ancak bazı rivayetlerde aktarılan peygamberin Mekke'den çıkacağı, Yesrib'e hicret edeceği ve nübüvvet mührü gibi ayrıntılar hakkında Zeyd b. Amr'ın bir malumata sahip olmasının mümkün olmadığı kanaatindeyiz. Çünkü Kur'ân-1 Kerîm'de: "Sen, bu Kitâb'ın sana vahyolunacağını ummuyordun. (Bu) ancak Rabbinden bir rahmet (olarak gelmiş)tir. O halde sakın kâfirlere arka çıkma!" âyeti bulunmaktadır. ${ }^{37}$ Âyette de açıkça görüldügü üzere $\mathrm{Hz}$. Peygamber'in kendisine nübüvvet verileceği konusunda bir ümidi ve beklentisi bulunmamaktaydı. Şayet gönderilecek elçinin Mekke'den çıkacağı ve Yesrib'e hicret edeceği gibi ayrıntılar birileri tarafından biliniyor ve başkalarına anlatılıyor olsaydı sadece Hz. Peygamber değil tüm Mekkeliler peygamber olabilme ümidine sahip olurdu. Buna ek olarak Hz. Peygamber, tebliği Mekke'de başarıya ulaşmayınca kendisi ve Müslümanlar için bir hicret yurdu arayışına girip Tâif'e gitmez, doğrudan Yesrib'e giderdi. Bu sebeple insanların bir peygamber beklentisine sahip olmalarını ihtimal dâhilinde görmekle birlikte bunun ayrıntıları hakkında herhangi bir malumata sahip olamayacaklarını düşünüyoruz.

\section{Zeyd b. Amr'ın Dinî Görüşleri ve İbadetler Konusundaki} Tavrı

Yukarıda aktardığımız rivayetlerde de açıkça görüldüğü üzere Zeyd b. Amr Kureyş'in içerisinde bulunduğu dinî durumdan hoşlanmıyor ve onlara açıç̧a muhalefet ediyordu. O, putlara tapmayıp

35 İbn İshâk, es-Sîre, 60-65; İbn Sa'd, et-Tabakât, 1/126; krş. İhsan Arslan, "Risâlet Beklentisi ve Hz. Peygamber'in Doğumu Esnasında Meydana Gelen Olayların Değerlendirilmesi", Recep Tayyip Erdoğan Üniversitesi Sosyal Bilimler Dergisi 7 (2018), 239-265.

36 Bk. es-Saff 61/6, el-A'râf 7/157.

37 el-Kasas 28/86. 
ilah olarak yalnızca Allah'ı kabul ediyordu. Putlar için kurban kesilmesini ayıpladığı gibi bu hayvanların etlerinden de yemiyordu. Hatta bazı kaynaklarda Zeyd b. Amr'ın putlara ibadet ettikleri için Kureyş'i ayıplayan ilk kişi olduğu aktarılmaktadır. ${ }^{38}$

Rivayetlerde açıkça görüldügü üzere Zeyd b. Amr'ın Allah'ı birleyen bir muvahhid olduğu konusunda şüphe bulunmamaktadır. O, bu tavrına doğru mantıkî çıkarımlar sayesinde sahip olmuştu. Örneğin, Zeyd b. Amr Allah'tan başkasının adına kurban kestikleri için Kureyşlileri ayıplar ve bu hayvanların etlerinden yemezdi. Niçin bu şekilde davrandığını da Kureyşlilere şöyle açıklamıştı: "Koyunları Allah yarattı. Gökten indirdiği yağmur ile bu koyunların yemesi için bitkiler yarattı. Buna rağmen siz bunları görmezden gelerek Allah'tan başkası adına bu hayvanları kurban ediyorsunuz. Ben kesilirken üzerine Allah'ın adının anılmadığı bir hayvanı yemem." ${ }^{39}$

Ancak Zeyd b. Amr din alanında özellikle ibadetler konusunda neredeyse hiçbir bilgiye sahip değildi. Amr b. Luhay el-Huzâît ile başlayan Mekke civarındaki çok tanrılı dinî inanış Hz. İbrâhîm ve Hz. İsmâîl'in getirdikleri tevhid dinine ait bilginin neredeyse tamamen ortadan kalkmasına sebep olmuştu. Var olan bilgiler de çok tanrılı inanç içerisinde büyük oranda bozulmuştu. Zeyd b. Amr bu bilgisizliğini şikâyet sadedinde: "Allah'ım! Eğer sana en güzel şekilde nasıl ibadet edileceğini bilseydim, o şekilde ibadet ederdim. Ancak bilmiyorum." diyordu. Ayrıca o, Allah'a nasıl secde edeceğini bilemediği için avcunun içini alnına değdiriyordu. ${ }^{41}$

Rivayetlerde Zeyd b. Amr'ın namazı ve haccı eda ediş şekliyle alakalı bazı bilgiler de aktarılmıştır. Zeyd b. Amr zeval vaktinden sonra Kâbe'ye dönerek içerisinde iki secde yaptığı bir rekâtlık bir namaz kılmıştı. Namazdan sonra da: “Bu, İbrâhîm'in ve İsmâîl'in kıblesidir. Ben asla putlara ibadet etmem, onlar için namaz kılmam ve kurban

38 İbn Habîb, el-Muhabber, 171-172; Cevâd Ali, el-Mufassal, 6/472.

39 İbn Sa'd, et-Tabakât, 3/291; Beyhakî, Delâilü'n-nübüvve, 2/122; İbn Asâkir, Târîh, 19/496; İbnü'l-Esîr, Üsdü'l-gâbe, 2/251.

40 Amr b. Luhay hakkında Hz. Peygamber: "Huzâalı Amr (b. Âmir) b. Luhay'1 cehennemde bağırsakları üzerinde sürünürken gördüm. $\mathrm{O}$, sâibeleri serbest bırakan ilk kişiydi." buyurmuştur. İbn Hişâm, es-Sîre, 1/111-112; Buhârî, "Menâkıb", 10.

${ }^{4}$ İbn İshâk, es-Sîre, 96; İbn Hişâm, es-Sîre, 1/262; İbnü'l-Esîr, Üsdü'l-gâbe, 2/252; İbn Kesîr, el-Bidâye, 3/316. 
436 | R. ERKOCAASLAN / Hanîflerden Zeyd b. Amr b. Nüfeyl' in Hayatı ve Şahsiyeti

kesmem. Putlar için kesilmiş olan hayvanların etlerini yemem. Fal oklarıyla da kısmet aramam. Ölünceye kadar da buraya yönelerek namaz kılacağım." demişti. ${ }^{42}$

Zeyd, hac esnasinda Arafat'ta vakfede bulunur ve: "Ey dengi ve ortağı bulunmayan Allah'ım! Emrine amadeyim!" şeklinde telbiye getirirdi. Arafat'tan inerken de şu sözleri söylerdi: “Ey Allah'ım! Sana kul olarak naif bir kalple ibadet etmeye geldim." 43

Zeyd b. Amr Kâbe'ye girdiği zaman da şöyle derdi: "Buyur Allah'ım! Sana ibadet ederek ve sana kul olarak İbrâhîm'in sığındığı şeye ben de sığındım. Hani İbrâhîm ayakta iken: 'Burnumu huzurunda yere sürüyorum. Bana ne kadar zorluklar yüklesen de sabrederim. Kibirlenmek değil iyilik isterim. Elbette sıcağın altında olan kişi istirahat eden gibi değildir.' demişti." 44

Esmâ bint Ebû Bekir'den gelen bir rivayette o, Zeyd b. Amr'in sırtını Kâbe'ye dayayarak: "Ey Kureyş topluluğu! Bugün kendimden başka İbrâhîm'in dini üzere olan hiç kimseyi görmüyorum." dediğine şahit olmuştur. ${ }^{45}$ Benzer şekilde Yesribli Hanîflerden Ebû Kays b. Eslet de: “İbrâhîm'in dini üzere olan benden ve Zeyd b. Amr'dan başka kimse yoktur." derdi. ${ }^{46}$

42 İbn Sa'd, et-Tabakât, 3/290; İbn Asâkir, Târîh, 19/503-504; İbn Hacer el-Askalânî, elIsâbe, $1 / 473$.

43 İbn Sa'd, et-Tabakât, 3/290; İbn Asâkir, Târîh, 19/504; İbn Kesîr, el-Bidâye, 3/323.

44 İbn İshâk, es-Sîre, 96; Belâzürî, Ensâb, 10/467; İbnü'l-Esîr, Üsdü'l-gâbe, 2/252.

45 İbn İshâk, es-Sîre, 96; İbn Sa'd, et-Tabakât, 3/291; Buhârî, "Menâkıbü'1-Ensâr", 24; Ebû Abdirrahmân Ahmed en-Nesâî, Sünenü'l-kübrâ, thk. Abdullâh b. Abdilmuhsin etTürkî (Beyrût: Müessesetü'r-Risâle, 2001), 7/324; Ebü'l-Kâsım Abdullâh b. Muhammed b. Abdilazîz b. el-Merzübân el-Begavî, Mu'cemü's-sahâbe, thk. Muhammedü'l-Emîn b. Muhammed Mahmûd el-Cekenî (Kuveyt: Mektebetü Dâru'lBeyân, 2000), 2/446-447; Ebü'l-Kâsım Müsnidü'd-dünyâ Süleymân b. Ahmed b. Eyyûb et-Taberânî, el-Mu'cemü'l-kebîr, thk. Hamdî Abdülmecîd Selefî (Kâhire: Mektebetü İbn Teymiyye, 1984), 24/82; Hâkim en-Nîsâbûrî, Müstedrek, 3/498; İbn Asâkir, Târîh, 19/504-505; İbnü'l-Esîr, Üsdü'l-gâbe, 2/252; Zehebî, Târîhu'l-İslâm, 2/91; İbn Kesîr, el-Bidâye, 3/316; Ebü'l-Hasen Nûrüddîn Alî b. Ebî Bekr b. Süleymân elHeysemî, Mecma 'u'z-zevâ'id ve menba 'i'l-fevâid (Beyrût: Dâru'l-Fikr, 1994), 9/696; İbn Hacer el-Askalânî, el-İsâbe, 2/250.

46 İbn Sa'd, et-Tabakât, 4/283; Cerrahoğlu, "Kur'an-1 Kerim ve Hanîfler”, 86. 
Yine benzer bir rivayette Esmâ bint Ebû Bekir, Zeyd b. Amr'nn sırtını Kâbe'ye dayayarak: "Ey Kureyş topluluğu! Zinadan (ribâdan"7) sakının. Çünkü o, yoksulluğa sebep olur." dediğini aktarmıştır. ${ }^{48}$ Ayrıca o, Câhiliye döneminde içki içmeyen şahıslar arasındaydı..$^{49}$

Zeyd b. Amr'in en takdire şayan hareketlerinden birisi de anne ve babaları tarafından öldürülmek istenen kız çocuklarını kurtarmaya çalışmasıydı. O, ailesi tarafından diri diri toprağa gömülecek olan kız çocuklarının babalarına gelerek: "Onu öldürmek için acele etme! Ben onun nafakasını üstlenirim." diyerek çocuğun bakımını üstlenirdi. Zeyd b. Amr bu kız çocukları büyüdüğü zaman babalarına tekrar gelerek: "İster kızını sana tekrar vereyim, istersen ben ona bakmaya devam edeyim." derdi. ${ }^{50}$

Zeyd b. Amr Mekke'de öldürülmek istenen her kız çocuğuna karşılık köle, cariye, at, deve veya koyun fidye vererek o kız çocuğunu ailesinden alırdı. Karşılığında fidye verdiği kız çocuklarının sayısı arttığı için fidye veremeyecek hale geldiğinde ise öldürülmek istenen kız çocuğunun ve annesinin iaşesini karşılard1. ${ }^{51}$

Zeyd b. Amr dinî söylemleri ve Kureyş'e yönelttiği uyarılar sebebiyle ömrünün sonlarına doğru bazı Kureyşlilerin düşmanca muameleleri ile karşı karşıya kalmıştı. Zeyd b. Amr'a düşmanlık eden kişilerin başında da amcası ve anne bir kardeşi olan Hattâb b. Nüfeyl gelmekteydi. Hattâb'ın eziyet ve baskıları sonucunda Zeyd, Mekke'yi terk ederek Hira Dağı'nda bir mağarada ikamet etmeye başladı. Hattâb, Kureyş gençlerinden bazılarını da görevlendirerek Zeyd'in Mekke'ye sokulmamasını istemişti. Bu sebeple Zeyd b. Amr ihtiyaçlarını karşılamak için Mekke'ye gireceği zaman onlara görünmemeye çalışırdı. Onlar, Zeyd'in Mekke'ye girdiğini öğrendikleri zaman kendisine eziyet ederek onu şehirden tekrar çıkarırlardı. Kureyşlilerin Zeyd b. Amr'a

47 İbnü'l-Esîr, Üsdü'l-gâbe, 2/252; Ebü'l-Fazl Cemâlüddîn Muhammed b. Mükerrem İbn Manzûr, Muhtasaru Târîhi Dımaşk, thk. Rûhiyye en-Nehhâs vd. (Dımaşk: Dâru'l-Fikr, 1984), 9/167.

48 İbn Asâkir, Târîh, 19/512-513; İbn Kesîr, el-Bidâye, 3/325; Atıyye, "Zeyd b. Amr", 599.

49 Cevâd Ali, el-Mufassal, 4/671.

50 İbn Sa'd, et-Tabakât, 3/291; Buhârî, "Menâkıbü'l-Ensâr", 24; Hâkim en-Nîsâbûrî, Müstedrek, 3/498; İ̉n Asâkir, Târîh, 19/505; Zehebî, Târîhu'l-İslâm, 2/88; İbn Kesîr, elBidâye, 3/316-317, 325; Adnan Demircan, Kızların Gömülerek Öldürülmesi ve Çok Kadınla Evlilik (İstanbul: Beyan Yayınları, 2008), 32-33.

51 Belâzürî, Ensâb, 10/469. 
438 | R. ERKOCAASLAN / Hanîflerden Zeyd b. Amr b. Nüfeyl' in Hayatı ve Şahsiyeti

eziyet etmelerinin sebebi onun kendileri gibi putlara tapmaması ve farklı bir inanışa sahip olmasıydı. Onlar Kureyşlilerin bazılarının Zeyd gibi bir inanışa sahip olmasından çekiniyorlardı. ${ }^{52}$ Zeyd b. Amr onların şerrinden uzaklaşmak için Hira Dağı'nda bir çadır kurarak burada münzevî bir hayat yaşamaya başlamıştı. Onun bu yaşantısı sebebiyle Mekkeliler Zeyd b. Amr'a "er-Râhib" derlerdi..$^{53}$

Burada karşımıza şöyle bir problem çıkmaktadır: Daha önceki rivayetlerde Zeyd b. Amr'ın hak dini aramak için Mekke dışına çıkmak istediğinde eşi Safiyye bint Hadramî'nin onu amcası Hattâb b. Nüfeyl'e şikâyet ettiği rivayeti geçmişti. Bu rivayette ise Zeyd b. Amr'in Mekke'ye sokulmadığı aktarılmaktadır. İki rivayeti şu şekilde telif edebiliriz: Zeyd b. Amr din arayışı içerisine ilk girdiği dönemlerde yaptığı uzun yolculuklar sebebiyle amcası ve akrabaları tarafından bu seyahatlerden men edilmiş olmalıdır. Ancak ilerleyen yıllarda sahip olduğu dini düşünceleri diğer insanları da etkileyecek bir biçimde dillendirmeye başladığı dönemde ise yine amcası ve akrabaları tarafından Mekke'ye sokulmamıştır.

Rivayetlerde de açıkça görüldüğü üzere Zeyd b. Amr hem ahlakı hem de yaşantısı itibariyle oldukça düzgün bir insandı. Tevhid açısından da Müslümanlardan farkı yoktu. Dolayısıyla nübüvvetten önce ölmüş olan Zeyd b. Amr'ın ahiretteki durumunu sahâbîler merak ediyorlardı. Bir gün Saîd b. Zeyd ve Hz. Ömer Rasûlullah'a gelerek Zeyd b. Amr'in durumunu sordular. Hz. Peygamber de: "Allah Zeyd b. Amr'a merhamet etsin ve onu bağışlasın. O, İbrâhîm'in dini üzere vefat etti." buyurdu. Bu olaydan sonra tüm Müslümanlar onun zikri geçtiğinde Zeyd için Allah'tan bağışlanma dilerlerdi. ${ }^{54}$

Yine benzer bir rivayette Saîd b. Zeyd Hz. Peygamber'e gelerek: “Ey Allah'ın Rasûlü! Kuşkusuz babam senin de bildiğin bir hal üzereydi. Eğer sana yetişmiş olsaydı, iman ederdi. Bu yüzden onun için

52 İbn İshâk, es-Sîre, 97; İbn Hişâm, es-Sîre, 1/267-268; Belâzürî, Ensâb, 10/469; Ebü'lHasen Ali b. el-Hüseyn el-Mes'ûdî, Mürûcü'z-zeheb ve me âdinü'l-cevher, thk. Kemâl Hasen Mer'î (Beyrût: el-Mektebetü'l-Asriyye, 2007), 1/56; İbn Asâkir, Târîh, 19/495; İbnü'l-Esîr, Üsdü'l-gâbe, 2/252.

53 Belâzürî, Ensâb, 10/469.

54 İbn Sa'd, et-Tabakât, 3/291; Belâzürî, Ensâb, 10/468; İbn Asâkir, Târîh, 19/512; İbn Kesîr, el-Bidâye, 3/326; krş. İbn İshâk, es-Sîre, 99-100; Tayâlisî, el-Müsned, 1/190; İbn Hişâm, es-Sîre, 1/262; Ahmed b. Hanbel, el-Müsned, 1/189-190; Begavî, Mu'cemü's-sahâbe, 2/447. 
Allah'tan mağfiret dile." dedi. Hz. Peygamber de Zeyd için mağfiret diledikten sonra: "Şüphesiz o, Kıyamet Günü'nde tek başına bir ümmet olarak gelecektir." buyurdu. ${ }^{55}$

Hz. Peygamber'in onun hakkında: “Zeyd b. Amr b. Nüfeyl tek başına bir ümmet olarak diriltilecektir." 56 "Benimle Meryem oğlu Îsâ arasında tek başına bir ümmet olarak diriltilecektir." buyurduğu aktarılmaktadir. ${ }^{57}$

Yine Hz. Peygamber'in onun hakkında: "Ben onu Cennet'te elbiselerini sürüklerken gördüm.",58 "Cennet'e girdim. Orada Zeyd b. Amr b. Nüfeyl'e ait iki ulu ağaç gördüm." buyurduğu da aktarılmaktadır. ${ }^{59}$

6. Zeyd b. Amr'ın Câhiliye Döneminde Hz. Peygamber ile Karşılaşması

Hz. Peygamber nübüvvetten önce Zeyd b. Amr ile karşılaşmış ve kendisiyle özellikle dinî konularda sohbet etmiştir. Bazı çağdaş araştırmalarda Hz. Peygamber'in Zeyd b. Amr ile konuşmayı çok sevdiği şeklinde bir iddia ${ }^{60}$ ortaya atılmış olmakla birlikte aşağıda aktaracağımız veya geçtiği kaynaklara işaret edeceğimiz olay muhtemelen bir defa meydana gelen bir karşılaşmanın değişik aktarımlarından ibarettir. Üstelik bu rivayetlerin tamamında olayın birden fazla kez meydana geldiğine dair bir emare de bulunmamaktadir.

Zeyd b. Hârise bu karşılaşmayı şu şekilde aktarmıştır: "Rasûlullah ile birlikte putlardan

birisinin yanına gidip onun için dişi bir koyun keserek, pişirdik ve bir torbaya koyduk.

55 Taberânî, el-Mu'cemü'l-kebîr, 1/152; Hâkim en-Nîsâbûrî, Müstedrek, 3/497; Beyhakî, Delâilü'n-nübüvve, 2/124; Ebû Abdillâh Şemseddîn Muhammed ez-Zehebî, Siyeru a'lâmi'n-nübelâ, thk. Şu'ayb el-Arnaût vd. (Beyrût: Müessesetü'r-Risâle, 1982), 1/129130; Heysemî, Mecma 'u'z-Zevâ'id, 9/694.

56 Ahmed b. Hanbel, el-Müsned, 1/190; Ebû Muhammed Abdullah b. Müslim İbn Kuteybe, el-Ma'ârif (Beyrût: Dâru'l-Kütübi'l-İlmiyye, 2003), 35; Belâzürî, Ensâb, 10/467/468; İbn Hazm, Cemheretü ensâbi'l-Arab, 151; İbn Asâkir, Târîh, 19/500; İbn Kesîr, el-Bidâye, 3/325-326.

57 Nesâî, Sünenüll-kübrâ, 7/324; Begavî, Mu'cemü's-sahâbe, 2/445; İbn Asâkir, Târîh, 19/511; İbn Kesîr, el-Bidâye, 3/326; Heysemî, Mecma 'u'z-Zevấ'id, 9/692.

58 İbn Sa'd, et-Tabakât, 3/290; İbn Kesîr, el-Bidâye, 3/322-323; İbn Hacer el-Askalânî, elİsâbe, 2/251-252; krş. Belâzürî, Ensâb, 10/467.

59 İbn Asâkir, Târîh, 19/512; Zehebî, Târîhu'l-İslâm, 2/91; İbn Kesîr, el-Bidâye, 3/327.

60 Neşet Çağatay, İslâmdan Önce Arap Tarihi ve Cahiliye Çağı (Ankara: AÜİFY, 1957), 149. 
440 | R. ERKOCAASLAN / Hanîflerden Zeyd b. Amr b. Nüfeyl'in Hayatı ve Şahsiyeti

Sonra Rasûlullah beni yanına alarak Mekke'nin sıcak bir gününde yola çıktı. Bir vadinin üst tarafına geldiğimizde Zeyd b. Amr b. Nüfeyl ile karşılaştı. Birbirlerini Câhiliye selamıyla selamladılar. Rasûlullah ona: 'Kavminin senden hoşlanmadığını görüyorum' deyince, Zeyd b. Amr: 'Vallahi! Beni sevmemeleri, benim yaptığım yanlış bir hareket sonucunda meydana gelmiş bir olay değildir. Ben, onların dalalet üzerinde olduklarını gördüm. Hak dini bulmak için yola çıkıp Yesrib'deki din adamlarına geldim. Onları hem Allah'a ibadet eder hem de ona şirk koşar halde buldum ve aradığım dinin bu olmadığına karar verdim. Sonra Hayber, Fedek ve Eyle'deki din adamlarına giderek onların da aynı vaziyette olduklarını gördüm. Sonra Şam'daki din adamlarından biri bana: 'Sen, Cezîre'deki (Hîre'deki) bir şeyhten başkasının tâbi olmadı̆̆ı bir dini soruyorsun.' dedi. Bunun üzerine bu şeyhin yanına gelerek geliş sebebimi ona söyledim. Şeyh bana: 'Bütün bu gördüklerin dalalettedir. Sen Allah'ın ve meleklerin dini olan bir dini soruyorsun. Senin beldende insanları bu dine davet eden bir peygamber ya çıktı ya da çıkacaktır. Geri dön, onu tasdik et, ona tabi ol ve getirdiklerine iman et.' dedi. Ancak hâlâ bir peygamber ortaya çıkmadı.' dedi. Devemizi çöktürüp daha önce kızarttığımız etten Zeyd b. Amr'a ikram ettik. Zeyd b. Amr: 'Bu nedir?' diye sorduğunda biz: 'Bu, put için kestiğimiz dişi koyunun etidir.' dedik. Zeyd b. Amr: 'Allah'tan başkası için kesilen hiçbir şeyi yemem.' dedi ve sonra birbirimizden ayrıldık. İsâf ve Nâile adında iki tane bakırdan yapılmış put vardı. Rasûlullah Kâbe'yi tavaf ederken ben de yanındaydım ve bu sırada bir putun yanından geçerken ona dokundum. Rasûlullah bana: 'Ona dokunma.' buyurdu. Ben de kendi kendime: 'Ona kesinlikle dokunacağım ve ne söyleyeceğine bakacağım.' dedim. Ona tekrar dokununca Rasûlullah: 'Ona dokunmaman söylenmedi mi!' buyurdu. Onu üstün kılan ve kendisine Kitâb'1 indirene yemin olsun ki! Kendisine peygamberlik gelene kadar hiçbir putu selamlamadı. Rasûlullah'a nübüvvet verilmeden önce Zeyd b. Amr b. Nüfeyl vefat etti. Rasûlullah onun hakkında: 'Kıyamet günü tek başına bir ümmet olarak diriltilecektir.' buyurdu." 61

Bu rivayet pek çok farklı şekillerde aşağıda aktardığımız âlimlerin eserleri vasıtasıyla günümüze ulaşmıştır. Rivayetler içerisinde en uzun anlatıma sahip olması sebebiyle Nesâî'nin rivayetini örnek olarak aktarmayı uygun gördük. Bu rivayetin değişik varyantlarının İbn İshâk (öl. 151/768), ${ }^{62}$ Rebî‘ b. Habîb (öl. 180/796?), ,63 Tayâlisî (öl. 204/819), ${ }^{64}$ İbn

61 Nesâî, Sünenü'l-kübrâ, 7/325-326.

62 İbn İshâk, es-Sîre, 98.

63 Ebû Amr er-Rebî’ b. Habîb b. Amr el-Ezdî el-Ferâhîdî el-Basrî, el-Câmi'u's-sahîh (elMüsned), thk. Abdullah b. Humeyd es-Sâlimî (Kâhire: Matba'atü's-Selefiyye, 1930), 18.

64 Tayâlisî, el-Müsned, 1/190. 
Sa'd (öl. 230/845), ${ }^{65}$ Ahmed b. Hanbel (öl. 241/855), ${ }^{66}$ Buhârî (öl. 256/870), ${ }^{67}$ Belâzürî (öl. 279/892), ${ }^{68}$ Bezzâr (öl. 292/905), ${ }^{69}$ Nesâ̂̂ (öl. 303/915), ${ }^{70}$ Ebû Ya'lâ el-Mevsilî (öl. 307/919), ${ }^{71}$ Begavî (öl. 317/929), ${ }^{72}$ İbn Düreyd (öl. 321/933), ${ }^{73}$ İbn Hibbân (öl. 354/965), ${ }^{74}$ Taberânî (öl. 360/971), ${ }^{75}$ Beyhakî (öl. 458/1066), ${ }^{76}$ İbn Abdilber (öl. 463/1071), ${ }^{77}$ İbn Asâkir (öl. 571/1176), ${ }^{78}$ Süheylî (öl. 581/1185), ${ }^{79}$ İbnü'l-Esîr (öl. 630/1233), ${ }^{80}$ Zehebî (öl. 748/1348) $^{81}$ ve Heysemî (öl. 807/1405) ${ }^{82}$ gibi birçok âlim tarafından bize ulaştırıldığını görmekteyiz.

$\mathrm{Bu}$ rivayet ve benzerleri Hz. Peygamber'in nübüvvetten önceki dinî durumu hakkında genel kabulün dışında bir tablo ortaya koyduğu için bu konu hakkında pek çok özel çalışma ve yorum yapılmıştır. ${ }^{83}$

65 İbn Sa'd, et-Tabakât, 3/291.

66 Ahmed b. Hanbel, el-Müsned, 1/189, 2/68-69, 89-90.

67 Buhârî, "Zebâih", 16, “Menâkıbü'1-Ensâr", 24.

68 Belâzürî, Ensâb, 10/467-468.

69 Ebû Bekr Ahmed b. Amr b. Abdilhâlik el-Bezzâr, el-Bahrü'z-zehhâr (el-Müsned), thk. Mahfûzurrahman Zeynullah (Beyrût: Müessesetü Ulûmi'1-Kur'ân, 1988), 12/272.

70 Nesâî, Sünenü'l-kübrâ, 7/325-326.

71 Ahmed b. Alî b. el-Müsennâ et-Temîmî Ebû Ya'lâ el-Mevsılî, Müsned, thk. Hüseyin Selîm Esed (Dımaşk: Dâru'l-Me'mûn li't-Türâs, 1990), 13/170-173.

72 Begavî, $M u^{\prime}$ cemü's-sahâbe, 2/441-444.

73 Ebû Bekr Muhammed b. el-Hasen İbn Düreyd, el-İştikâk, thk. Abdüsselâm Muhammed Hârûn (Beyrût: Dâru'l-Cîl, 1991), 134.

74 Ebû Hâtim Muhammed İbn Hibbân, Sahîhu İbn Hibbân bi tertîbi İbn Balabân, thk. Şuayb el-Arnaût (Beyrût: Müessesetü'r-Risâle, 1993), 12/46-47.

75 Taberânî, el-Mu 'cemü'l-kebîr, 1/152, 5/86-88, 12/297-298.

76 Beyhakî, Delâilü'n-nübüvve, 2/121-122, 124-126.

77 İbn Abdilber, el-İstî'âb, 2/617.

78 İbn Asâkir, Târîh, 19/507, 508-509.

79 Ebü'l-Kâsım Abdurrahmân b. Abdillâh b. Ahmed el-Has'amî es-Süheylî, er-Ravzü'lünüf fì tefsîri's-Sîreti'n-nebeviyye li'bni Hişâm, thk. Mecdî b. Mansûr b. Seyyid el-Şûrâ (Beyrût: Dâru'1-Kütübi'l-İlmiyye, ts.), 2/121-122.

80 İbnü'l-Esîr, Üsdü'l-gâbe, 2/251.

81 Zehebî, Siyeru a'lâmi'n-nübelâ, 1/220-222; Zehebî, Târîhu'l-İslâm, 2/85-86, 87-88, 90.

82 Heysemî, Mecma 'u'z-Zevâ'id, 9/694, 695-696.

83 Meir Jacob Kister, "A Bag of Meat: A Study of an Early Hadīth", Bulletin of the School of Oriental and African Studies 33/2 (1970), 267-274; Meir Jacob Kister, "Torbadaki Et (Bir İlk Dönem Rivayeti Üzerinde Çalışma)", çev. Enbiya Yıldırım, Cumhuriyet Üniversitesi İlahiyat Fakültesi Dergisi 4 (2000), 167-178; Ali Osman Ateş, “Putlara Kurban Kesme ve Allah'tan Başkası Adına Kesilenlerden Yeme Konusunda Hz. 
442 | R. ERKOCAASLAN / Hanîflerden Zeyd b. Amr b. Nüfeyl' in Hayatı ve Şahsiyeti

$\mathrm{Bu}$ rivayet hakkında bizim de ayrıntılı bir değerlendirme yapmamız maalesef çalışmanın bir makale boyutunun üzerine çıkmasına sebep oldu. Buna rağmen bazı yüzeysel tespit ve değerlendirmeler yapabiliriz.

Öncelikle Hz. Peygamber, Zeyd b. Amr ile karşılaştığında Zeyd b. Hârise de Rasûlullah'ın yanındaydı. Hz. Hatice, Zeyd b. Hârise'yi Hz. Peygamber'e evliliklerinden sonra hediye etmişti. ${ }^{84} \mathrm{~Hz}$. Peygamber'in $\mathrm{Hz}$. Hatice ile evlendiğinde yirmi beş yaşında olduğ $\mathrm{u}^{85}$ ve Zeyd $b$. Amr'ın da Hz. Peygamber otuz beş yaşındayken vefat ettiği göz önüne alınırsa $^{86}$ bu olayın Hz. Peygamber yirmi beş ila otuz beş yaş arasındayken gerçekleştiği ortaya çıkar.

Yine bu rivayetten çıkan sonuçlardan biri Hz. Peygamber'in Câhiliye adetlerini sorgulamaya başlamasında Zeyd b. Amr'ın etkisinin olduğudur. Daha önce zikrettiğimiz üzere Zeyd b. Amr'ın: “Ey Kureyş topluluğu! Bugün kendimden başka İbrâhîm'in dini üzere olan hiç kimseyi görmüyorum." sözleri de o günün Mekke'sinde tevhid inancına sahip olan Zeyd b. Amr'dan başka kimsenin bulunmadığını göstermektedir. Ancak şöyle bir değerlendirme de yapılabilir: Mekke'de tevhid inancina sahip olan birileri bulunuyor olsa da bu insanlar görüşlerini Zeyd b. Amr gibi herkesle paylaşmadıkları için Zeyd b. Amr'ın yaşamış olduğu gibi bir sürgün yaşamamışlar veya onun maruz kaldığı bir düşmanlığa maruz kalmamışlardır.

Rivayetten anlaşılan diğer bir gerçek de Hz. Peygamber'in gördüğü dinî baskılar sebebiyle Mekke dışında yaşamak zorunda kalan

Peygamber'in Tutumu", Dokuz Eylül Üniversitesi İlahiyat Fakültesi Dergisi 4 (1987), 363-401; Fahri Hoşab, "Hadîs Rivâyetinde İhtisâr -Hanîf Zeyd b. Amr'a Dair Bir Buhârî Rivâyeti Örneği-", Turkish Studies 12/10 (2017), 132-138; krş. Muhammed Hamîdullah, İslâm Peygamberi, çev. Salih Tuğ (İstanbul: İrfan Yayımcılık, 2001), 1/49; Emile Dermenghem, Hz. Muhammed ve Risâleti, çev. Ahmet Ağırakça (İstanbul: İnsan Yayınları, 1997), 78-80; İsrafil Balc1, Peygamberlik Öncesi Hz. Muhammed (Ankara: Ankara Okulu Yayınları, 2015), 300-306; Emine Demil, Hz. Peygamber'in Risâlet Öncesi Hayatına Dair Rivâyetler (Ankara: Ankara Üniversitesi, Sosyal Bilimler Enstitüsü, Doktora Tezi, 2016), 260-276; İhsan Arslan, "Risâlet Öncesi Hz. Peygamber'in Dinî Durumu", Recep Tayyip Erdoğan Üniversitesi İlahiyat Fakültesi Dergisi 17 (Haziran 2020), 110-119.

84 İbn Sa'd, et-Tabakât, 3/29-30; Belâzürî, Ensâb, 1/467.

85 İbn Hişâm, es-Sîre, 1/224; İ̉n Sa'd, et-Tabakât, 1/105.

86 İbn Sa'd, et-Tabakât, 3/291; Belâzürî, Ensâb, 10/468, 469; Hâkim en-Nîsâbûrî, Müstedrek, 3/496. 
Zeyd b. Amr hakkında bilgi sahibi olduğudur. Ancak Hz. Peygamber yine de Zeyd b. Amr'a Mekkelilerin kendisini niçin sevmediğini sorarak yaşadığı sıkıntıların sebebini bir de onun bakış açısı ile dinlemek istemiştir. Kanaatimizce bu olay Hz. Peygamber'in olayları farklı açılardan görmeyi ve değerlendirmeyi arzulayan sorgulayıcı bir zihne sahip olduğunu göstermektedir. Zeyd b. Amr da Hz. Peygamber'e Mekkelilerin kendisini sevmemelerinin sebebinin onun kötü bir insan olmasından kaynaklanmadığını, Mekkeliler dalalette oldukları için kendisine düşmanlık ettiklerini ifade etmiştir.

Zeyd b. Amr yine bu karşılaşma esnasında yaptığı dinî yolculuklardan ve tevhid inancindan Hz. Peygamber ve Zeyd b. Hârise'ye bahsetmiştir. Gerçeği öğrenmeye yatkın, tertemiz bir fitrata sahip olan Hz. Peygamber, Zeyd b. Amr'ın konuşmalarından çok etkilenmiştir. Muhtemelen o güne kadar kendisine hiç kimsenin bahsetmediği bu konular onun çok ilgisini çekmiş hızlı muhakeme yeteneği sayesinde o günden sonra putlara saygı manasına gelebilecek herhangi bir davranışta bulunmadığı gibi ailesinin bir ferdi gibi olan Zeyd b. Hârise'yi de putlara tazim etmemesi konusunda uyarmıştır.

Zeyd b. Amr'in Hz. Muhammed'in peygamberliğinde etkili olduğu, onu yönlendirdiği şeklinde bir iddia da bulunmakla birlikte ${ }^{87} \mathrm{bu}$ tarz iddialar taraflı oldukları için ciddiye almaya gerek bulunmamaktadır. Hz. Muhammed'e peygamberliğin Allah tarafından verildiğine inanmayan oryantalistlerin bu peygamberlik için bir köken bulmaya çalışmaları gayet doğaldır.

\section{Zeyd b. Amr'a Atfedilen Şiirler}

Kaynaklarımızda Zeyd b. Amr'ın okuduğu ve bazılarının kendisine aidiyetinin de şüpheli olduğu belirtilen bazı şiirler aktarılmıştır. Bu şiirlerde bir dönem putlara taptığını da ifade eden Zeyd b. Amr genel olarak vahdaniyet, Allah'ın büyüklügü̈, putlara tapmanın kötülüğü ve faydasızlığı gibi konulardan bahsetmiştir. ${ }^{88}$

87 Lecker, "Zayd b. 'Amr", 11/475; krş. İbrahim Sarıçam vd., İngiliz ve Alman Oryantalistlerin Hz. Muhammed Tasavvuru (İstanbul: Nobel Yayın Dağıtım, 2011), 170, 218-219, 233, 238.

88 İbn İshâk, es-Sîre, 96-97; İbn Hişâm, es-Sîre, 1/262-263; Belâzürî, Ensâb, 10/468; İbn Asâkir, Târîh, 19/513-516; İbn Kesîr, el-Bidâye, 3/327-330; İbrahim Ethem Polat, "Hanif Şairlerin Şiirlerinde Monoteist Yapı", Nüsha Şarkiyat Araştırmaları Dergisi 1/1 (2001), 126-127. 
444 | R. ERKOCAASLAN / Hanîflerden Zeyd b. Amr b. Nüfeyl'in Hayatı ve Şahsiyeti

Zeyd b. Amr'a isnat edilen şiirlerinden biri şöyledir:

Tek bir Rabbe mi yoksa bin Rabbe mi,

Boyun eğeyim, işler taksim olunduğu zaman.

Lât'ı da Uzzâ'yı da hepsini azlettim.

Metanetli, sabırlı kişi böyle yapar.

Uzzâ'ya da onun iki kızına da ibadet etmem.

Benî Amr'ın iki putunu da ziyaret etmem.

Hübel'e de ibadet etmem, o rabbimiz olsa da

Aklımızın kıt olduğu eski zamanlarda

Şaşıım, şaşılacak şey var gecelerde,

Ve gündüzlerde, onları basîr olan bilir... ${ }^{89}$

\section{Zeyd b. Amr'in Vefatı}

Zeyd b. Amr'ın vefatıyla ilgili birbirinden oldukça farklı ve telif edilemez iki farklı bilgi bulunmaktadır. İlkine göre Zeyd b. Amr Hz. Peygamber otuz beş yaşındayken Kureyş' in Kâbe'yi yeniden inşa ettiği sene vefat etmiş olup ${ }^{90}$ Hira Dağ' ${ }^{\prime}$ nın eteğine defnedilmiştir. ${ }^{91}$ Zeyd $b$. Amr'ın oğlu Saîd b. Zeyd'den aktarılan bir rivayet de bu bilgiyi desteklemektedir. ${ }^{92}$

Konuyla ilgili ikinci bir rivayette ise Hz. Peygamber'e nübüvvet verildiği esnada Zeyd $b$. Amr'ın Şam bölgesinde bulunduğu aktarılmaktadır. Zeyd b. Amr, Hz. Peygamber'in nübüvvetini ilan ettiğini haber alınca onu görmek üzere yola çıkmış ancak Belkâ' bölgesinde bulunan Meyfa'a ${ }^{93}$ (Mebka'a) ${ }^{94}$ köyünün halkı tarafından

89 İbn İshâk, es-Sîre, 96-97; İbn Hişâm, es-Sîre, 1/262-263.

90 İbn Sa'd, et-Tabakât, 3/291; Belâzürî, Ensâb, 10/468, 469; Hâkim en-Nîsâbûrî, Müstedrek, 3/496; İ̉n Asâkir, Târîh, 19/512; İbn Kesîr, el-Bidâye, 3/326; V. Vacca, "Zeyd b. Amr", Milli Ĕ̆itim Bakanlı̆̆ı İslâm Ansiklopedisi (Eskişehir: MEB Yayınları, 1997), 13/547; Mehmet Apaydın, Siyer Kronolojisi (İstanbul: Kuramer Yayınları, 2018), 274.

91 İbn Sa'd, et-Tabakât, 3/291-292; Belâzürî, Ensâb, 10/469; İbn Asâkir, Târîh, 19/516; İbn Kesîr, el-Bidâye, 3/327.

92 İbn Hacer el-Askalânî, el-i̇sâbe, 2/251.

93 Şam yakınlarındaki Belkâ' bölgesinde bulunan bir köydür. İbn Hazm, Cemheretü ensâbi'l-Arab, 151; Abdullâh b. Abdilazîz el-Bekrî, Mu'cemü me'sta'cem min esmâ'i'lbilâd ve'l-mevâzi', thk. Mustafa es-Sakkâ (Beyrût: Âlemü'l-Kütüb, 1945), 4/1284.

94 Bu bölgede Lahm veya Cüzâm kabilesinden bir grup yaşamaktaydı. İbn İshâk, esSîre, 98-99; İbn Hişâm, es-Sîre, 1/268; İbn Habîb, el-Muhabber, 172; Belâzürî, Ensâb, 10/468; İbn Kesîr, el-Bidâye, 3/318-319; Bazı kaynaklarda Zeyd b. Amr'1 öldürenlerin Hristiyan oldukları da aktarılmaktadır. İbn Kuteybe, el-Ma'ârif, 35; Zeyd b. Amr'ın 
öldürülmüştür. ${ }^{95}$ Belâzürî bu rivayeti aktardıktan sonra Zeyd b. Amr'ın nübüvvetten beş yıl önce öldügüüü belirten rivayetin daha makul olduğunu ifade etmiştir. ${ }^{96}$

Zeyd b. Amr'ın vefatı üzerine Varaka b. Nevfel'in onun hakkında okuduğu bir şiir de kaynaklarımızda aktarılmıştır. Varaka b. Nevfel bu şiirinde bir muvahhid olan Zeyd b. Amr'in Allah'ın rahmetine kavuştuğunu ifade etmiştir. ${ }^{97}$

Görüldüğü üzere Zeyd b. Amr her halükarda Rasûlullah'1 peygamber olarak görememiş olmakla birlikte onun bazı âlimler tarafından sahâbî olarak kabul edildiği şeklinde bir iddia bulunmaktadır. ${ }^{98}$ Ancak tespit edebildiğimiz kadarıyla o, sadece Begavî tarafından sahâbî olarak kabul edilmiştir. ${ }^{99}$ Bazı çalışmalarda Zeyd b. Amr'ın sahâbî olarak kabul edilmesinin sebebi şu şekilde açıklanmıştır: "Bazı rivayetlerde geçtiği üzere Zeyd b. Amr bir peygamberin geleceğine iman ediyordu. Üstelik kendisi bir muvahhid olup Rasûlullah'1 da görmüştü. Onun tüm bu özellikleri sebebiyle kendisini sahâbî saymak mümkün olabilir." 100 Yapılan bu açıklama oldukça makul gibi gözükse de yukarıda Hz. Peygamber'den aktardı̆̆ımız rivayetlerde Zeyd b. Amr'in Hz. Îsâ ile Hz. Peygamber arasında ayrı bir ümmet olarak diriltileceği aktarılmıştı. Dolayısıyla tüm üstün özelliklerine rağmen, Hz. Peygamber'in ümmetinden sayılmayan bir kişinin sahâbî olarak görülmesi kanaatimizce doğru olmayacaktır.

\section{Sonuç}

Zeyd b. Amr, Câhiliye döneminde yaşayarak Hz. Peygamber'e nübüvvet verilmeden önce vefat etmiş olan Mekkeli bir Hanîf'tir. Onun

bazı Gassânî melikleri tarafından zehirlenerek öldürüldüğü şeklinde rivayetler de bulunmaktadır. Mes'ûdî, Mürûcü'z-zeheb, 1/56; Cevâd Ali, el-Mufassal, 6/471.

95 Belâzürî, Ensâb, 10/470; İbn Hazm, Cemheretü ensâbi'l-Arab, 151; Bekrî, Mu'cem, 4/12841285; İbn Kesîr, el-Bidâye, 3/327.

96 Belâzürî, Ensâb, 10/470.

97 İbn İshâk, es-Sîre, 99; İbn Hişâm, es-Sîre, 1/268-269; İbn Kuteybe, el-Ma'ârif, 36; Belâzürî, Ensâb, 10/469.

98 İbn Hacer el-Askalânî, el-İsâbe, 2/250; Cerrahoğlu, "Kur'an-1 Kerim ve Hanîfler", 86; Lecker, "Zayd b. 'Amr", 11/474; krş. Mehmet Efendioğlu, "Sahâbe", Türkiye Diyanet Vakfi İslâm Ansiklopedisi (İstanbul: TDV Yayınları, 2008), 35/491.

99 Begavî Zeyd b. Amr'ın nübüvvetten önce öldüğünü kaydettikten sonra: “Kuşkusuz Nebî'ye iman etmişti." demektedir. Begavî, Mu'cemü's-sahâbe, 2/441.

100 Atryye, "Zeyd b. Amr", 598. 
446 | R. ERKOCAASLAN / Hanîflerden Zeyd b. Amr b. Nüfeyl' in Hayatı ve Şahsiyeti

ne zaman doğduğu ve kaç yaşında vefat ettiği konusunda bilgimiz bulunmamaktadır. Annesi üvey oğlu ile evlenip bu evlilikten Zeyd b. Amr dünyaya geldiği için kendisi maktî bir kişidir. Hem kendi ağzından hem de başka şahısların şahitliği onun yaşadığı dönemde Mekke'de Hanîf olan tek kişi olduğunu göstermektedir.

Bazı şiirlerinde de ifade ettiği üzere kendisi bir dönem diğer hemşerileri gibi putlara tazimde bulunmuştur. Onu bu görüşünden vazgeçiren bir olay yaşanmış mıdır, yoksa kendi aklî çıkarımları sayesinde mi Allah'ın birliğine inanmaya başlamıştır, bu konuda kaynaklarımızda herhangi bir malumat bulunmamaktadır. Zeyd b. Amr putlara ibadet etmenin yanlışlığının farkına varınca pek çok beldeyi ziyaret ederek doğru bir din arayışına girmiştir. Rivayetlerden anladığımız kadarıyla doğru bir din bulabilmek için yapılan bu seyahatler birden fazla kez gerçekleşmiştir. Zeyd b. Amr'ın doğru dini bulabilmek için Yesrib, Hayber, Fedek, Eyle, Şam, Musul, Cezîre, Belkâ ve Hîre gibi pek çok bölgeyi ziyaret ettiği anlaşılmaktadır. Yaptığ seyahatler esnasında kalbini mutmain eden bir din bulamayan Zeyd b. Amr bilgisine ulaşabildiği ölçüde ataları Hz. İbrâhîm ve Hz. İsmâîl'in dini üzere kalmaya karar vermiştir. Tabi aradan geçen uzun yıllar bu dinin gerekliliklerini unutturduğu için o, sahip olduğu oldukça sınırlı bilgi üzerinden Allah'a ibadet etmeye çalışmıştır. Kaynaklarımızda onun namaz ve hac ibadeti konusunda yaptığı bazı uygulamalardan bahsedilmektedir. Ayrıca o salim bir aklın da bulabileceği içki, zina ve ribâ gibi kötü adet ve alışkanlıklardan da uzak kalmaya çalışmıştır.

Zeyd b. Amr belli bir noktadan sonra hemşerilerini de yanlış uygulama ve inançları yüzünden eleştirmeye başlayınca Mekkelilerin, özellikle de amcası ve anne bir kardeşi olan Hattâb b. Nüfeyl'in düşmanlığına maruz kalmıştır. Hatta kendisi Mekke'ye sokulmadığı için Hira Dağı'nda bir mağarada veya bu bölgede kurduğu bir çadırda yaşamaya mecbur kalmıştır.

Zeyd b. Amr'ın yaptığı en güzel davranışlardan birisi de aileleri tarafından gömülmek istenen kız çocuklarını kurtarması hatta bu uğurda bazen bu $\mathrm{kız}$ çocuklarının ailelerine para vermesidir. Bu davranışı da zihniyet ve davranış olarak çağının oldukça ilerisinde bir insan olduğunu göstermesi açısından yeterlidir.

Zeyd b. Amr'ın vefatının ardından eşi Fâtıma bint Ba'ce'nin ve çocukları Saîd b. Zeyd ve Âtike bint Zeyd'in ilk dönemde İslâm'a girmiş 
olmaları onun aile üyelerini de olumlu yönde etkilediğini göstermektedir.

Zeyd b. Amr nübüvvetten evvel Hz. Peygamber ile görüşerek onun da Câhiliye adetlerini sorgulamaya başlamasına vesile olmuştur.

Yine konu ile ilgili farklı rivayetler bulunmakla birlikte Zeyd b. Amr muhtemelen Hz. Peygamber otuz beş yaş civarındayken Mekke'de vefat etmiş ve Hira Dağı'nın eteğine defnedilmiştir. Hz. Peygamber'den gelen pek çok rivayette onun tek başına bir ümmet olarak haşredileceği ifade edilmektedir. Yine onun Cennetlik olduğuna dair rivayetler de bulunmaktadır.

\section{Kaynakça}

Ahmed b. Hanbel, Ebû Abdillâh. el-Müsned. 6 Cilt. İstanbul: Çağrr Yayınları, 1992.

Algül, Hüseyin. "Ficâr". Türkiye Diyanet Vakfı İslâm Ansiklopedisi. 13/52. İstanbul: TDV Yayınları, 1996.

Apaydın, Mehmet. Siyer Kronolojisi. İstanbul: Kuramer Yayınları, 2018.

Arslan, İhsan. "Risâlet Beklentisi ve Hz. Peygamber'in Doğumu Esnasında Meydana Gelen Olayların Değerlendirilmesi". Recep Tayyip Erdoğan Üniversitesi Sosyal Bilimler Dergisi 7 (2018), 239-295. Arslan, İhsan. "Risâlet Öncesi Hz. Peygamber'in Dinî Durumu". Recep Tayyip Erdoğan Üniversitesi İlahiyat Fakültesi Dergisi 17 (Haziran 2020), 106-125.

Ateş, Ali Osman. "Putlara Kurban Kesme ve Allah'tan Başkası Adına Kesilenlerden Yeme Konusunda Hz. Peygamber'in Tutumu". Dokuz Eylül Üniversitesi İlahiyat Fakültesi Dergisi 4 (1987), 363-402.

Atıyye, Hâmid Hamîd. "Zeyd b. Amr b. Nüfeyl el-Adevî". Mecelletü Diyâlâ 44 (2010), 596-612.

Balc1, İsrafil. Peygamberlik Öncesi Hz. Muhammed. Ankara: Ankara Okulu Yayınları, 2. Basım, 2015.

Begavî, Ebü'l-Kâsım Abdullâh b. Muhammed b. Abdilazîz b. elMerzübân. Mu'cemü's-sahâbe. thk. Muhammedü'l-Emîn b. Muhammed Mahmûd el-Cekenî. 5 Cilt. Kuveyt: Mektebetü Dâru'1Beyân, 2000.

Bekrî, Abdullâh b. Abdilazîz. Mu'cemü me'sta'cem min esmâ'i'l-bilâd ve'lmevâzi'. thk. Mustafa es-Sakkâ. 4 Cilt. Beyrût: Âlemü'l-Kütüb, 1945. 
448 | R. ERKOCAASLAN / Hanîflerden Zeyd b. Amr b. Nüfeyl' in Hayatı ve Şahsiyeti

Belâzürî, Ebü'l-Hasen Ahmed b. Yahyâ. Ensâbü'l-eşrâf. thk. Muhammed Hamîdullah vd.. 13 Cilt. Beyrût: Dâru'l-Fikr, 1417.

Beyhakî, Ebû Bekr Ahmed b. el-Hüseyn b. Alî. Delâilü'n-nübüvve ve ma'rifetü ahvâli sâhibi'ş-şerî'a. thk. Abdülmu'tî Kal'acî. 7 Cilt. Beyrût: Dâru'l-Kütübi'l-i̇lmiyye, 1988.

Bezzâr, Ebû Bekr Ahmed b. Amr b. Abdilhâlik. el-Bahrü'z-zehhâr (elMüsned). thk. Mahfûzurrahman Zeynullah. 20 Cilt. Beyrût: Müessesetü Ulûmi'1-Kur'ân, 1988.

Buhârî, Ebû Abdillâh Muhammed. el-Câmi'u's-sahîh. 3 Cilt. İstanbul: Çă̆rı Yayınları, 1992.

Buhl, Fr. "Hanîf". Milli Ĕ̆itim Bakanlı̆̆ı İslâm Ansiklopedisi. 5/1/215-217. Eskişehir: MEB Yayınları, 1997.

Cerrahoğlu, İsmail. "Kur'an-1 Kerim ve Hanîfler". Ankara Üniversitesi İlahiyat Fakültesi Dergisi 11/1 (1963), 81-92.

Cevâd Ali. el-Mufassal fì târîhi'l-'Arab kable'l-İslâm. 10 Cilt. Bağdâd: Câmiatü Bağdâd, 2. Basım, 1993.

Çağatay, Neşet. İslâmdan Önce Arap Tarihi ve Cahiliye Çağı. Ankara: AÜİFY, 1957.

Demil, Emine. “Hz. Peygamber'in Risâlet Öncesi Hayatına Dair Rivâyetler". Ankara: Ankara Üniversitesi, Sosyal Bilimler Enstitüsü, Doktora Tezi, 2016.

Demircan, Adnan. Kızların Gömülerek Öldürülmesi ve Çok Kadınla Evlilik. İstanbul: Beyan Yayınları, 2008.

Dermenghem, Emile. Hz. Muhammed ve Risâleti. çev. Ahmet Ağırakça. İstanbul: İnsan Yayınları, 1997.

Ebû Dâvûd, Süleymân b. el-Eş‘as b. İshâk es-Sicistânî. es-Sünen. 5 Cilt. İstanbul: Çağrı Yayınları, 1992.

Ebû Ya'lâ el-Mevsılî, Ahmed b. Alî b. el-Müsennâ et-Temîmî. Müsned. thk. Hüseyin Selîm Esed. 14 Cilt. Dımaşk: Dâru'1-Me'mûn li'tTürâs, 2. Basım, 1990.

Efendioğlu, Mehmet. "Sahâbe". Türkiye Diyanet Vakfı İslâm Ansiklopedisi. 35/491-500. İstanbul: TDV Yayınları, 2008.

Hâkim en-Nîsâbûrî, Ebû Abdillâh Muhammed. Müstedrek ale's-Sahîhayn. thk. Mustafa Abdülkâdir Atâ'. 5 Cilt. Beyrût: Dâru'l-Kütübi'lİlmiyye, 2. Basım, 2002.

Hamîdullah, Muhammed. İslâm Peygamberi. çev. Salih Tuğ. 2 Cilt. İstanbul: İrfan Yayımcilık, 5. Basım, 2001. 
Heysemî, Ebü'l-Hasen Nûrüddîn Alî b. Ebî Bekr b. Süleymân. Mecma 'u'z-zevâ'id ve menba 'i'l-fevâid. 10 Cilt. Beyrût: Dâru'l-Fikr, 1994.

Hoşab, Fahri. "Hadîs Rivâyetinde İhtisâr -Hanîf Zeyd b. Amr'a Dair Bir Buhârî Rivâyeti Örneği-". Turkish Studies 12/10 (2017), 123-142.

İbn Abdilber, Ebû Ömer Cemâleddîn Yûsuf. el-İstî'âb fî ma'rifeti'l-ashâb. thk. Ali Muhammed el-Becâvî. 4 Cilt. Beyrût: Dâru'l-Cîl, 1992.

İbn Asâkir, Ebü'l-Kâsım Ali b. el-Hasen. Târîhu medîneti Dımaşk. thk. Muhibbüddîn Ebî Sa'îd Ömer b. Garâme el-Amravî. 80 Cilt. Beyrût: Dâru'l-Fikr, 1995.

İbn Düreyd, Ebû Bekr Muhammed b. el-Hasen. el-isştikâk. thk. Abdüsselâm Muhammed Hârûn. Beyrût: Dâru'1-Cîl, 1991.

İbn Habîb, Ebû Ca'fer Muhammed. el-Muhabber. thk. İlse Lichtenstadter. Beyrût: Dârü'l-Âfâki'l-Cedîde, ts.

İbn Hacer el-Askalânî, Ebü'l-Fazl Şihâbeddîn Ahmed b. Ali. el-İsâbe fî temyîzi's-sahâbe. 8 Cilt. Beyrût: Dâru'l-Fikr, 2001.

İbn Hazm, Ebû Muhammed Alî b. Ahmed b. Saîd. Cemheretü ensâbi'lArab. thk. Abdüsselâm Muhammed Hârûn. Kâhire: Dâru'1-Ma'ârif, 5. Basım, 1982.

İbn Hibbân, Ebû Hâtim Muhammed. Sahîhu İbn Hibbân bi tertîbi İbn Balabân. thk. Şuayb el-Arnaût. 18 Cilt. Beyrût: Müessesetü'r-Risâle, 2. Basım, 1993.

İbn Hişâm, Ebû Muhammed Cemâleddîn Abdülmelik. es-Sîretü'nnebeviyye. thk. Mustafa es-Sakâ vd.. 4 Cilt. Beyrût: Dâru'l-İhyâi'tTürâsi'l-Arabî, 1994.

İbn İshâk, Ebû Abdullah Muhammed. Sîretü İbn İshâk. thk. Muhammed Hamîdullah. Fas: y.y., 1976.

İbn Kesîr, Ebü'l-Fidâ İmâdüddîn İsmâîl b. Şihâbiddîn Ömer. el-Bidâye $v e^{\prime} n$-nihâye. thk. Abdullah b. Abdilmuhsin et-Türkî. 21 Cilt. Cîze: Hicr, 1997.

İbn Kuteybe, Ebû Muhammed Abdullah b. Müslim. el-Ma'ârif. Beyrût: Dâru'l-Kütübi'l-İlmiyye, 2. Basım, 2003.

İbn Mâce, Ebû Abdillâh Muhammed b. Yezîd. es-Sünen. 2 Cilt. İstanbul: Çağrı Yayınları, 1992.

İbn Manzûr, Ebü'l-Fazl Cemâlüddîn Muhammed b. Mükerrem. Lisânü'lArab. thk. Abdullah Ali el-Kebîr vd.. 55 Cilt. Kâhire: Dâru'lMa'ârif, ts. 
450 | R. ERKOCAASLAN / Hanîflerden Zeyd b. Amr b. Nüfeyl' in Hayatı ve Şahsiyeti

İbn Manzûr, Ebü'l-Fazl Cemâlüddîn Muhammed b. Mükerrem. Muhtasaru Târîhi Dımaşk. thk. Rûhiyye en-Nehhâs vd.. 31 Cilt. Dımaşk: Dâru'l-Fikr, 1984.

İbn Sa'd, Ebû Abdillâh Muhammed. et-Tabakâtü'l-kübrâ. thk. Muhammed Abdülkâdir Atâ. 9 Cilt. Beyrût: Dâru'l-Kütübi'lİlmiyye, 2. Basım, 2012.

İbnü'l-Esîr, Ebü'l-Hasen İzzeddîn Ali. Üsdü'l-gâbe fî ma 'rifeti's-sahâbe. thk. Halîl Me'mûn Şeyhâ. 5 Cilt. Beyrût: Dâru'l-Ma'rife, 4. Basım, 2009.

Karaman, Hayrettin vd.. Kur'ân-ı Kerîm ve Açılamalı Meâli. Ankara: TDV Yayınları, 13. Basım, 2005.

Kister, Meir Jacob. "A Bag of Meat: A Study of an Early Ḥadìth". Bulletin of the School of Oriental and African Studies 33/2 (1970), 267-275.

Kister, Meir Jacob. "Torbadaki Et (Bir İlk Dönem Rivayeti Üzerinde Çalışma)". çev. Enbiya Yıldırım. Cumhuriyet Üniversitesi İlahiyat Fakültesi Dergisi 4 (2000), 167-178.

Kuzgun, Şaban. "Hanîf". Türkiye Diyanet Vakfı İslâm Ansiklopedisi. 16/3339. İstanbul: TDV Yayınları, 1997.

Lecker, Michael. "Zayd b. 'Amr". The Encyclopaedia of Islam, New Edition. ed. C. E. Bosworth vd.. 11/474-475. Leiden: Brill, 2002.

Mâtürîdî, Ebû Mansûr Muhammed b. Muhammed b. Mahmûd. Te'vîlâtü'l-Kur'ân. thk. Bekir Topaloğlu vd.. 18 Cilt. İstanbul: Mizan Yayınevi, 2006.

Mes'ûdî, Ebü'l-Hasen Ali b. el-Hüseyn. Mürûcü'z-zeheb ve me âdinü'lcevher. thk. Kemâl Hasen Mer'î. 4 Cilt. Beyrût: el-Mektebetü'lAsriyye, 2007.

Müslim, Ebü'l-Hüseyin Müslim b. el-Haccâc. el-Câmi' 'u's-sahîh. 3 Cilt. İstanbul: Çağrı Yayınları, 1992.

Nesâ̂i, Ebû Abdirrahmân Ahmed. Sünenü'l-kübrâ. thk. Abdullâh b. Abdilmuhsin et-Türkî. 12 Cilt. Beyrût: Müessesetü'r-Risâle, 2001.

Özkan, Halit. "Zeyd b. Amr". Türkiye Diyanet Vakfı İslâm Ansiklopedisi. 44/316-317. İstanbul: TDV Yayınları, 2013.

Öztürk, Mustafa. Cahiliyeden İslamiyet'e Kadın. Ankara: Ankara Okulu Yayınları, 2. Basım, 2013.

Pırlanta, İsmail, Hz. Said bin Zeyd. İstanbul: Beyan Yayınları, 2020.

Polat, İbrahim Ethem. "Hanif Şairlerin Şiirlerinde Monoteist Yap1". Nüsha Şarkiyat Araştırmaları Dergisi 1/1 (2001), 124-134. 
Rebî̀ b. Habîb, Ebû Amr er-Rebî‘ b. Habîb b. Amr el-Ezdî el-Ferâhîdî elBasrî. el-Câmi'u's-sahîh (el-Müsned). thk. Abdullah b. Humeyd esSâlimî. Kâhire: Matba 'atü's-Selefiyye, 2. Basım, 1930.

Sarıçam, İbrahim vd.. Ingiliz ve Alman Oryantalistlerin Hz. Muhammed Tasavouru. İstanbul: Nobel Yayın Dağıtım, 2011.

Süheylî, Ebü'l-Kâsım Abdurrahmân b. Abdillâh b. Ahmed el-Has'amî. er-Ravzü'l-ünüf fî tefsîri's-Sîreti'n-nebeviyye li'bni Hişâm. thk. Mecdî b. Mansûr b. Seyyid el-Şûrâ. 4 Cilt. Beyrût: Dâru'l-Kütübi'1İlmiyye, ts.

Taberânî, Ebü'l-Kâsım Müsnidü'd-dünyâ Süleymân b. Ahmed b. Eyyûb. el-Mu'cemü'l-kebîr. thk. Hamdî Abdülmecîd Selefî. 25 Cilt. Kâhire: Mektebetü İbn Teymiyye, 2. Basım, 1984.

Taberî, Ebû Ca'fer Muhammed b. Cerîr b. Yezîd el-Âmülî. Târîhu'l-ümem ve'l-mülûk. 6 Cilt. Beyrût: Dâru'l-Kütübi'l-İlmiyye, 5. Basım, 2012.

Tayâlisî, Ebû Dâvûd Süleymân b. Dâvûd b. el-Cârûd. el-Müsned. thk. Muhammed b. Abdülmuhsin et-Türkî. 4 Cilt. Cîze: Hicr, 1999.

Tirmizî, Ebû Îsâ Muhammed b. Îsâ b. Sevre. es-Sünen. 5 Cilt. İstanbul: Çă̆rı Yayınları, 1992.

Vacca, V. "Zeyd b. Amr". Milli Ĕ̆itim Bakanlığı İslâm Ansiklopedisi. 13/546-547. Eskişehir: MEB Yayınları, 1997.

Zehebî, Ebû Abdillâh Şemseddîn Muhammed. Siyeru a'lâmi'n-nübelâ. thk. Şu'ayb el-Arnaût vd.. 25 Cilt. Beyrût: Müessesetü'r-Risâle, 2. Basım, 1982.

Zehebî, Ebû Abdillâh Şemsüddîn Muhammed. Târîhu'l-İslâm ve vefeyâtü'l-meşâhîr ve'l-a 'lâm. 53 Cilt. Beyrût: Dâru'l-Kitâbi'l-Arabî, 2. Basım, 1990.

Zemahşerî, Ebü'1-Kâsım Mahmûd b. Ömer b. Muhammed el-Hârizmî. el-Keşşâf an hakâ'ikı gavâmizi't-tenzîl ve uyûni'l-ekâvîl fî vücûhi't-te'vîl. thk. Âdil Ahmed Abdülmevcûd - Ali Muhammed Mu'avviz. 6 Cilt. Riyâd: Mektebetü'1-Ubeykân, 1998.

Zübeyrî, Ebû Abdillâh Mus'ab b. Abdillâh b. Mus‘ab. Kitâbü Nesebi Kureyş. thk. E. Lévi-Provençal. Kâhire: Dâru'l-Ma'ârif, 3. Basım, 1951. 